\title{
Design of a chemical probe for the Bromodomain and Plant Homeodomain Finger-containing
}

(BRPF) family of proteins

Niall Igoe, ${ }^{a}$ Elliott D. Bayle, ${ }^{a}$ Cynthia Tallant, ${ }^{b}$ Oleg Fedorov, ${ }^{b}$ Julia C. Meier, ${ }^{b}$ Pavel Savitsky, ${ }^{b}$ Catherine Rogers, ${ }^{\mathrm{b}}$ Yannick Morias, ${ }^{\mathrm{c}}$ Sarah Scholze, ${ }^{\mathrm{c}}$ Helen Boyd, ${ }^{\mathrm{c}}$ Danen Cunoosamy, ${ }^{\mathrm{c}}$ David M. Andrews, ${ }^{d}$ Anne Cheasty, ${ }^{\text {e }}$ Paul E. Brennan, ${ }^{b}$ Susanne Müller, b,f Stefan Knapp, b,f,g and Paul V. Fisha,*

a UCL School of Pharmacy, University College London, 29/39 Brunswick Square, London, WC1N $1 \mathrm{AX}, \mathrm{UK}$

b Nuffield Department of Clinical Medicine, Structural Genomics Consortium, University of Oxford, Old Road Campus Research Building, Roosevelt Drive, Oxford, OX3 7DQ, UK

c AstraZeneca, Innovative Medicines \& Early Development, Pepparedsleden 1, 43183 Mölndal, Sweden

d AstraZeneca Discovery Sciences, Darwin Building, Cambridge Science Park, Cambridge CB4 OFZ, UK

e CRT Discovery Laboratories, Jonas Webb Building, Babraham Research Campus, Cambridge CB22 3AT, UK

${ }^{\dagger}$ Buchmann Institute for Molecular Life Sciences, Max-von-Laue-Strasse 15, D-60438 Frankfurt am Main, Germany

g Institute for Pharmaceutical Chemistry, Johann Wolfgang Goethe-University, Max-von-Laue-Strasse 9, D-60438 Frankfurt am Main, Germany 


\section{ABSTRACT}

The bromodomain and PHD finger-containing (BRPF) family are scaffolding proteins important for the recruitment of histone acetyltransferases of the MYST family to chromatin. Here we describe NI-57 (16) as new pan-BRPF chemical probe of the bromodomain (BRD) of the BRPFs. Inhibitor 16 preferentially bound the BRD of BRPF1 and BRD1 over BRPF3, whereas binding to BRD9 was weaker. 16 has excellent selectivity over non-class IV BRD proteins. Target engagement of BRPF1B and BRD1 with 16 was demonstrated in nanoBRET and FRAP assays. The binding of 16 to BRPF1B was rationalized through an X-ray co-crystal structure determination which showed a flipped binding orientation when compared to previous structures. We report studies that show $\mathbf{1 6}$ has functional activity in cellular assays by modulation of the phenotype at low $\mu$ molar concentrations in both cancer and inflammatory models. Pharmacokinetic data for $\mathbf{1 6}$ was generated in mouse with single dose administration showing favourable oral bioavailability.

\section{KEYWORDS}

BRPF1, BRPF2, BRD1, BRPF3, BRD7, BRD9, ATAD2, BET, bromodomain, chemical probe, NI-57 


\section{INTRODUCTION}

Lysine acetylation is a key modification which, in combination with other posttranslational modifications, constitutes the epigenetic code, a complex language that is interpreted by protein interaction modules, so called reader domains that specifically interact with sequences harbouring these modifications. Aberrant acetylation is a hallmark of many diseases and acetyl lysine reader domains have therefore emerged as potential targets for treatment. ${ }^{1,2}$

Lysine acetylation is specifically recognized by bromodomains (BRD), a family of 61 diverse protein domains that all share a conserved helical fold comprising a left-handed bundle of four $\alpha$ helices ( $\alpha Z$, $\alpha A, a B, a C$ ), linked by loop regions of variable length (ZA and $B C$ loops). ${ }^{3}$ Despite this structural conservation, the sequence diversity within the BRD family is high facilitating the development of specific inhibitors. Furthermore, the deep and mainly hydrophobic acetyl-lysine binding sites in most BRDs have good predicted druggability ${ }^{4}$ and this property has been validated experimentally by the recent development of a large diversity of BRD inhibitors. ${ }^{2,5}$

The first potent BRD inhibitors have been developed against the BET family (BRD2, BRD3, BRD4, BRDT) ${ }^{6-10}$ The disease modifying properties of these inhibitors and their general availability resulted in a number of clinical studies, mainly in oncology. ${ }^{11}$ The success of pre-clinical BET inhibitors spurred the development of inhibitors outside this family which now covers most of the main BRD families ${ }^{5}$ including BRDs of BAZ2A/B, ${ }^{12,13}$ CREBBP/P300, ${ }^{14-16}$ SMARCA2/4, ${ }^{17,18}$ BRD9/7, ${ }^{19,20}$ PCAF, ${ }^{21}$ ATAD2 $^{22}$ as well as promiscuous inhibitors called bromosporines. ${ }^{23}$ In addition, inhibitors for members of the BRDs of the Bromodomain and Plant Homeodomain (PHD) Finger-containing (BRPF) family of proteins (BRPF1, BRPF2 (also termed BRD1) and BRPF3) have been identified. ${ }^{24-30}$ 


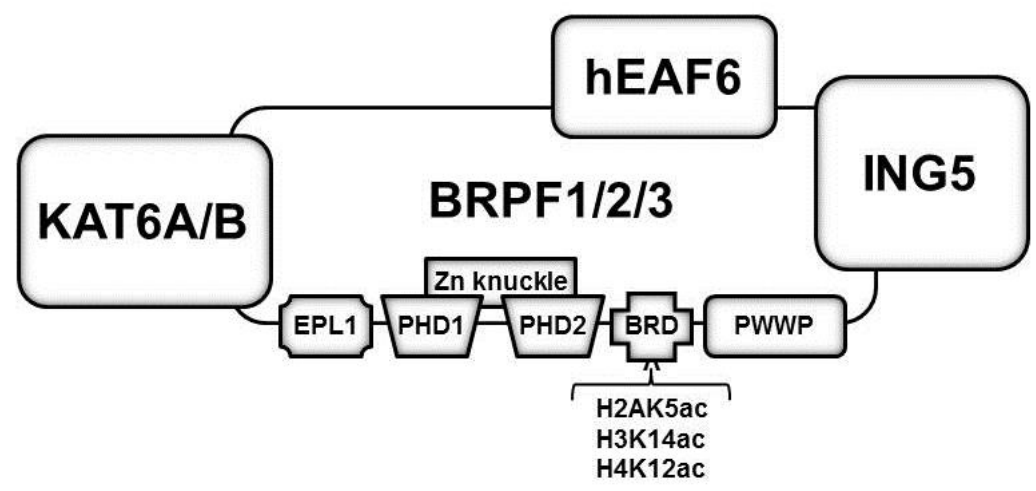

Figure 1. Cartoon representation of BRPFs as part of the tetrameric MYST scaffolding complex along with ING5 and hEAF6. The BRPFs contain multiple chromatin reader domains.

BRPF family members are scaffolding proteins that harbour a diversity of protein interaction domains including two N-terminal PHD domains linked by a $\mathrm{Zn}^{2+}$ knuckle (PZP [PHD-Zn knuckle-PHD] domain) (targeting unmodified sequences in histone H3), a BRD as well as a C-terminal PWWP domain binding to tri-methylated $\mathrm{K} 36$ in histone $\mathrm{H} 3 .{ }^{31}$ The BRD in BRPF has been described to interact with a number of histone acetylation sites such as H2AK5ac, H4K12ac and H3K14ac. ${ }^{32}$ BRPF proteins are central scaffolds that recruit histone acetyl-transferases (HATs) of the MYST family assembling a chromatin complex that also contains the ING tumour suppressor and hEAF6 (an EPCassociated protein) (Figure 1). ${ }^{33}$ The scaffolding function of BRPF proteins is required for substrate specificity of MYST HATs. Alternative scaffolding proteins of the JADE family that share the BRPF Nterminus but lack the C-terminal bromo and PWWP domains direct MYST complexes towards the H4 tail whereas the BRPF containing complexes are targeted to histone H3. ${ }^{34}$ MYST/BRPF2 complexes play important roles in the regulation of erythropoiesis. Deletion of the BRPF2 gene in mice for instance results in severe anaemia due to impaired foetal liver erythropoiesis. ${ }^{35}$ We recently demonstrated that the BRD in BRPF is required for differentiation of monocytes into bone resorbing osteoclasts suggesting important function of the acetyl-lysine reader function of BRPF/MYST regulating bone turnover. ${ }^{36}$ Therapeutic targeting of BRPF1 by small molecules may also be valuable in the myelomonocytic morphologic subtype of acute myeloid leukemia (AML). ${ }^{30}$ 
<smiles>CCc1cc2c(cc1NS(=O)(=O)c1ccc(Br)cc1C)n(C)c(=O)n2CC</smiles>

OF-1

pan BRPFs<smiles>CCCOc1cc(OCCCCNC)cc(Oc2cc3c(cc2NS(=O)(=O)c2ccc(OC)c(OC)c2)n(C)c(=O)n3C)c1</smiles>

IACS-9571

dual TRIM24-BRPF1<smiles>[X]c1cc2c(cc1NC(=O)c1ccccc1OC)n(C)c(=O)n2C</smiles>

PFI-4

GSK6853

BRPF1<smiles>COc1ccc(Oc2cc3c(cc2NS(=O)(=O)c2ccc(OC)c(OC)c2)n(C)c(=O)n3C)cc1</smiles>

'compound 34'

TRIM24-BRPF1/2<smiles>Cc1cc2c(cc1N1C(=O)c3cccc4c(CCCO)ccc(c34)C1=O)n(C)c(=O)n2C</smiles>

BAY-299

BRPF2 and TAF1

Chart 1. Chemical probes and inhibitors for the bromodomain of the BRPFs, TRIM24-BRPFs and BRPF2-TAF1. The 1,3-dimethyl benzimidazolone, which acts as a acetyl-lysine mimic, is shown within the blue box.

Recent studies have identified the 1,3-dimethyl benzimidazolone template as binding to the BRD of BRPF1 and this core has been optimised to give three chemical probes as either the pan-BRPF BRD inhibitor OF-1,24 or as the selective BRPF1 BRD inhibitors PFI-425 and GSK685326 (Chart 1). The 1,3dimethyl benzimidazolone template has also been used to identify TRIM24-BRPF inhibitors such as 
IACS-9571 $1^{27}$ and others. ${ }^{28}$ BAY-299 is a potent inhibitor of BRPF2 and the second BRD of TAF1 and has been published with an inactive partner as a negative control. ${ }^{29}$ Although these inhibitors all share some common structural features with respect to their acetyl-lysine mimic, their pharmacology profiles and biopharmaceutical properties are quite different.

The use of small molecule inhibitors as chemical probes to investigate the relationship between the target and disease is significantly enhanced when two structurally orthogonal chemical probes are employed. We reported the discovery of a BRD fragment hit which was optimized by structure guided design to NI-42 (15) as an inhibitor of the BRD of the BRPF proteins (Table 1). ${ }^{30}$ Compound 15 has an $\mathrm{N}$-methylquinolin-2-one as the acyl-lysine mimic which offers a different secondary pharmacology fingerprint profile to the benzimidazolones. Quinolin-2-one 15 is a biased, potent inhibitor of the BRD of the BRPFs with good selectivity over non-class IV BRD proteins.

Table 1. Selected properties of 15<smiles>Cc1cc2cc(NS(=O)(=O)c3ccc(C#N)cc3)ccc2n(C)c1=O</smiles>

NI-42 (15)

mw 353; $\operatorname{clog} P$ 2.5; tPSA 90

$\begin{array}{ll}\text { BRPF1 KD (ITC) } & 40 \mathrm{nM} \\ \text { BRPF2 KD (ITC) } & 210 \mathrm{nM} \\ \text { BRPF3 KD (ITC) } & 940 \mathrm{nM} \\ \text { BRD9 } \mathrm{K}_{\mathrm{D}} \text { (ITC) } & 1130 \mathrm{nM}\end{array}$

Selectivity vs non-Class IV BRDs:

$\Delta T_{\mathrm{m}}$ shift at $10 \mu \mathrm{M} \quad<1^{\circ} \mathrm{C}$

Our aims were to further explore the quinolin-2-one series and to design new small molecule inhibitors of the BRD of the BRPFs. Here we report detailed SAR studies that led to the discovery of a second generation chemical probe for the BRPFs with improved potency and selectivity over $\mathbf{1 5}$ which is suitable for cellular and in vivo studies. 


\section{RESULTS AND DISCUSSION}

Chemistry. The general methods for the synthesis of the quinolin-2(1H)-one sulfonamides 1-42 are outlined in Schemes 1 and 2. The 6-amino quinolin-2(1H)-ones 43-55 were reacted with the appropriate sulfonyl chlorides 56 in the presence of base to give the corresponding sulfonamides 1-9, 14-37 as previously described (Scheme 1). ${ }^{30}$ The amines 43-55 were generally prepared by published methods or the application of know procedures. The sulfonyl chlorides 56 were purchased from commercial sources or prepared by standard methods. The $\mathrm{N}$-alkyl sulfonamides $\mathbf{3 8 - 4 2}$ were prepared from the corresponding $\mathrm{N}-\mathrm{H}$ sulfonamides by deprotonation with $\mathrm{NaH}$ and reaction with the appropriate alkyl iodide 57 .

Scheme 1: General synthesis of sulfonamides 1-9, 14-42 
<smiles>[R]c1c(N)c([R])c2c([R])c([R])c(=O)n([R1])c2c1[R]</smiles>

$43-55$

$\mathrm{R} / \mathrm{ArSO}_{2} \mathrm{Cl}(56)$

Base<smiles>[R]c1c(NS([R17])(=O)=O)c([R])c2c([R])c([R])c(=O)n([R1])c2c1[R]</smiles>

$1-9,14-37$

$38-42$

Amines 43-55, with $\mathrm{H}$ unless otherwise stated:

43: $\quad \mathrm{R}^{1}=\mathrm{Me}$

44: $\quad \mathrm{R}^{1}=\mathrm{R}^{3}=\mathrm{Me}$

45: $\quad R^{1}=M e ; R^{3}=E t$

46: $\quad R^{1}=M e ; R^{3}=i P r$

47: $\quad R^{1}=M e ; R^{4}=M e$

48: $\quad R^{1}=M e ; R^{5}=F$

49: $\quad \mathrm{R}^{1}=\mathrm{Me} ; \mathrm{R}^{7}=\mathrm{OMe}$

50: $\quad R^{1}=\mathrm{Me} ; \mathrm{R}^{7}=\mathrm{OEt}$

51: $\quad R^{1}=\mathrm{Me} ; \mathrm{R}^{7}=\mathrm{OiPr}$

52: $\quad R^{1}=M e ; R^{7}=F$

53: $\quad R^{1}=M e ; R^{3}=M e ; R^{7}=O M e$

54: $\quad R^{1}=M e ; R^{3}=M e ; R^{8}=F$

55: $\quad \mathrm{R}^{1}=\mathrm{R}^{3}=\mathrm{Et}$<smiles>[R]c1c(N([R1])S(=O)(=O)[Ge])c([R])c2c([R])c([R])c(=O)n([R])c2c1[R]</smiles> 
Reversed sulfonamides 10-13 were prepared by an analogous reaction of quinolin-2-one-6-sulfonyl chloride 59 with the appropriate anilines 60 (Scheme 2).

Scheme 2: Synthesis of 1-methyl-2-oxo-1,2-dihydroquinoline-6-sulfonyl chloride (59) and 10-13.<smiles>Cn1c(=O)ccc2ccccc21</smiles>

58<smiles>Cn1c(=O)ccc2cc(S(=O)(=O)Cl)ccc21</smiles>

59<smiles>[Y]n1c(=O)ccc2cc(S(=O)(=O)Nc3cc[Y]cc3)ccc21</smiles>

$10-13$

Reagents and Conditions: (a) $\mathrm{HSO}_{3} \mathrm{Cl}, 95{ }^{\circ} \mathrm{C}, 77 \%$; (b) $\mathrm{ArNH}_{2}$ (60)(0.9 eq), pyridine (1.0 eq), $\mathrm{CH}_{2} \mathrm{Cl}_{2}$, rt, o/n, 39-79 \%; (c) For 11: 2-Aminobenzonitrile (0.9 eq), pyridine (1.0 eq), DMAP (0.1 eq), $\mathrm{CH}_{2} \mathrm{Cl}_{2}$, reflux, o/n, $15 \%$;

Screening Strategy. Compounds were screened for BRPF affinity by two complementary methods to develop SARs. Compounds were initially tested for BRPFs BRD binding $\left(\Delta T_{\mathrm{m}}\right)$ with a differential scanning fluorimetry (DSF) assay and then screened for inhibition $\left(\mathrm{IC}_{50}\right)$ of BRPF BRD activity as measured by the BROMOscan biochemical assay (Tables 2-4). BRD9 and BRD4(BD1) were routinely used as BRD counter screens to establish evidence of selectivity in both the DSF and BROMOscan assays. In general, there was a good correlation between the DSF and BROMOscan data for these compounds with very similar trends in ranked order of affinities. Preferred compounds were then evaluated for selectivity against a panel of 47 BRDs by DSF and inhibition of BRPF BRD activity was confirmed by independent evaluation by an AlphaScreen biochemical assay $\left(\mathrm{IC}_{50}\right)$. Finally, equilibrium dissociation constants $\left(\mathrm{K}_{\mathrm{D}}\right)$ were determined by isothermal titration calorimetry (ITC). 
Structure Activity Relationships. Earlier work. Previous SARs had identified phenyl sulfonamide 6 as having reasonable binding affinity for all three BRPFs with a preference for BRPF1 (IC50 $65 \mathrm{nM}$ ). These preliminary SARs were focussed on exploring three positions on this lead. The optimization of substituents on the phenyl ring of 6 identified a modest preference for a 4 -CN group $(7<<\approx 8 \approx 9$ ) and then modification of the groups at the $\mathrm{N} 1$ and $\mathrm{C} 3$ positions of the quinolin-2-one core showed that a 3-Me gave a significant increase in BRPF affinity leading to the discovery of $15 .{ }^{30}$ Hence, there was plenty of scope to further investigate this template with the aim of improving binding affinity for the BRPFs whilst reducing affinity for other BRDs, especially BRD9.

Design principles. It was also important to retain the beneficial physicochemical properties of 6 (mw 314; cLogP 2.0; tPSA 66; LE 0.46; LLE 5.2) by moderating the size and lipophilicity of new target compounds so as to be compatible with drug-like space. Additional guiding design principles were to avoid any reactive or potentially toxic groups, to have favourable biopharmaceutical properties, and to be chemically enabled. Modulation of these properties was achieved by the application of the lighter halogens (F), small alkyls (Me, Et, iPr), alkoxy (OMe, OEt, OiPr) and nitriles (CN) as substituents.

This new phase of SAR investigation was directed at: (1) broader range of substitution of the sulfonamide, including reversing the connectivity (Table 2); (2) introduction of groups at each of the available positions on the quinolin-2-one core (Table 3); and (3) substitution of the $\mathrm{NH}$ of the 6sulfonamide (Table 4). In addition to optimizing for BRPF activity, we also aimed to identify specific points of SAR that would remove BRPF activity to generate a matched inactive control, and to provide selective hits for other BRDs of the class IV proteins.

Simple sulfonamides. Simple alkyl sulfonamides $\mathbf{1 - 5}$ proved to be inferior to phenyl 6 with BRPF1 activity tracking with increased lipophilicity of the alkyl substituent. Reversing the sulfonamide connection offered no advantage with a small set of benzonitriles 11-13 when compared to 7-9, although the 2-CN reversed sulfonamide 11 seemed to show a preference for BRD9 over BRPF1 in the DSF assay albeit with relatively modest $\Delta T_{\mathrm{m}}$ values (Table 2).

Sulfonamide substitution. Further exploration of the aryl sulfonamide ring when combined with the 1,3-dimethylquinolin-2-one core identified our most potent BRPF inhibitors prepared so far (Table 3). Previously it had been shown that introduction of a 2-OMe $\mathbf{1 4}$ gave a potent inhibitor of BRPF1 although with some unwanted BRD4 activity. In addition, the 4-CN group was a preferred single 
substituent or could be combined with a second substituent at either the 2- or 3-position. ${ }^{30}$ Combining these points of SAR prompted the design and synthesis of the 2-OMe,4-CN analogue 16. Sulfonamide 16 showed improved BRPF1 activity in both the DSF and BROMOscan assays (BRPF1: $\Delta T_{\mathrm{m}} 12.3^{\circ} \mathrm{C}$; IC50 $3.1 \mathrm{nM}$; mw 383; cLogP 2.1; tPSA 99; LE 0.44; LLE 6.4) and was superior to either the mono-substituted analogues 2-OMe (14) or 4-CN (15). This result prompted the routine exploration of both the 4-CN and 2-OMe,4-CN benzene sulfonamide analogues in compound design, and 16 was selected for further evaluation including BRPF1B co-crystal structure determination.

The BRPF1B co-crystal structure with 16 was solved at $2.3 \AA$ (Figure 2). Quinolin-2-one 16 fitted in the lysine acetylated-binding site of BRPF1B as expected, maintaining the conserved $\mathrm{H}$-bond interaction with Asn708 and the water mediated H-bond with Tyr665. Additional key contacts specific of the core scaffold included a parallel and face-centered $\pi-\pi$ stacking interaction of Phe714 side chain with the quinolin-2-one moiety at approximately $3.7 \AA$. Moreover, the phenyl rotamer was pointing towards the benzonitrile ring at $3.9 \AA$ forming a $\mathrm{CH}-\pi$ interaction. Embedded into the hydrophobic and non-charged binding site, the shape complementarity of 16 to the protein interface was high (Figure 2a). Further compound stabilization was observed by means of a water mediated bridge interaction between the sulfonamide and the $2-\mathrm{MeO}$ group of the benzonitrile. Interestingly, an overlay of 16 with $\mathbf{N I - 4 8}(66)^{30}$ showed a flip of $180^{\circ}$ of the quinolin-2-one core with the N1-Me group pointing towards Tyr707 (Figure 2d and S2). This new scaffold conformation presented the lowest Bfactor values during compound fitting and refinement. This flip forced the benzonitrile group to move closer to the ZA-loop (Ile652). 

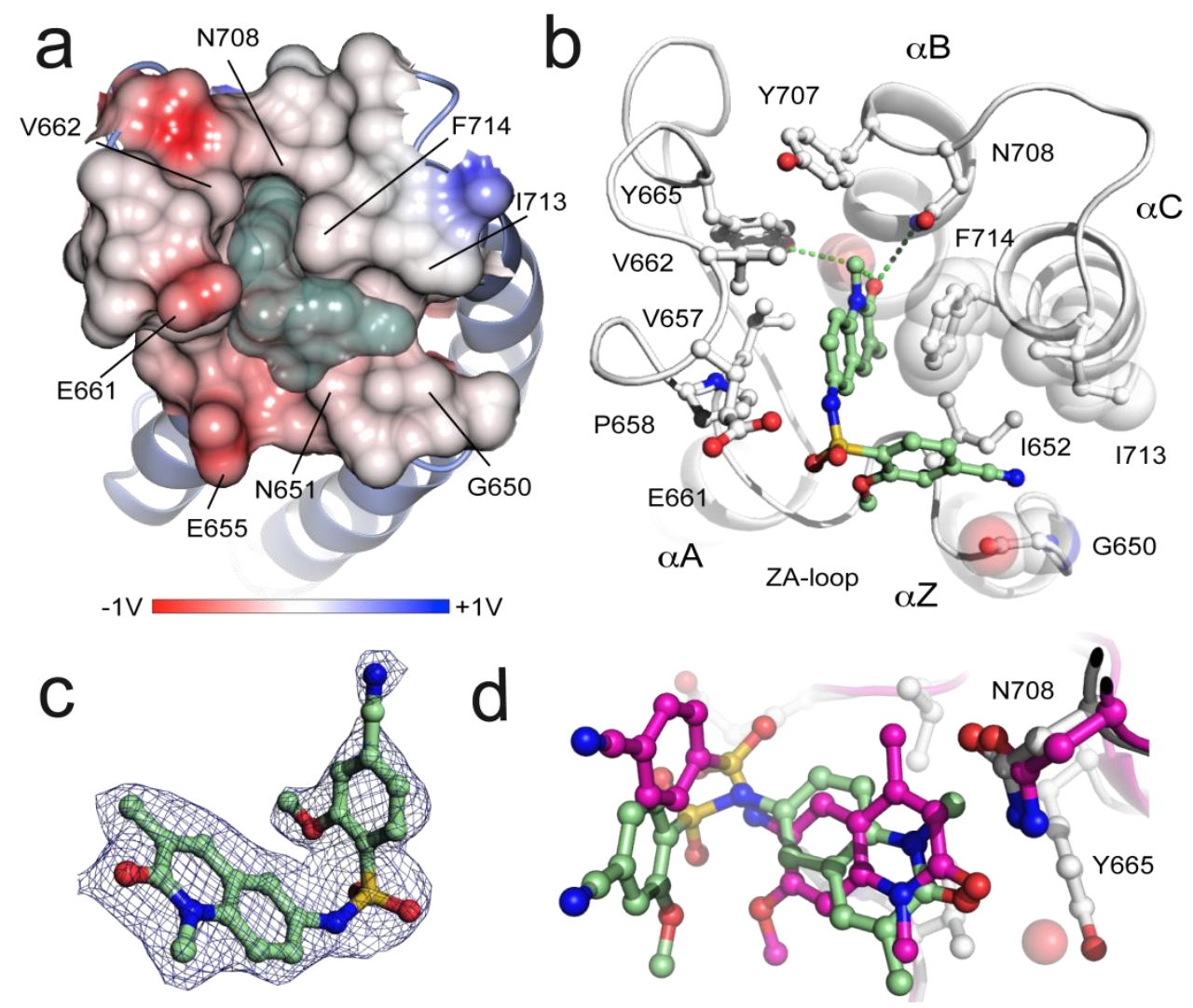

Figure 2. X-ray crystal structure of 16 (green) bound to BRPF1 (grey) (5MYG.pdb). (a) Electrostatic potential surface represented at the bromodomain binding site. (b) Close-up view of the interactions of 16 with the BRPF1 binding site displayed in cartoon and sticks. (c) 2Fo - Fc electron density map contoured at $1 \sigma$ showing electron density around 16. The figure shows the map for the fully refined structure. (d) Structural superposition of 16 with 66 (purple; 5T4V.pdb) in complex with BRPF1B.<smiles>COc1cc2c(cc1NS(=O)(=O)c1ccc(C#N)cc1)c(C)cc(=O)n2C</smiles>

NI-48 (66)

Quinolin-2-one substitution. Introduction of a limited number of single groups at specific positions on the quinolin-2-one core showed some advantage over hydrogen (e.g. 4-Me (21); 7-OMe (24) $\geq \mathrm{H}(\mathbf{9})$ ) but failed to improve BRPF1 activity to the same level as was achieved with a 3-Me substituent (15) (Table 3). Larger alkyls at $C 3$ such as 3 -Et $(\mathbf{1 7}, \mathbf{1 8})$ or $3-\operatorname{iPr}(\mathbf{1 9}, \mathbf{2 0})$ significantly reduced BRPF activity whereas groups at the 5-position (5-F (22); 5-OMe) were tolerated. Small alkoxy groups at $\mathrm{C} 7$ 
showed a modest beneficial effect with 23-26 and so a 7-OMe was combined with the 3-Me group on the quinolin-2-one core to see if these effects were additive.

A set of 6 preferred sulfonyl chlorides 56 were coupled with 6-amino-7-methoxy-1,3-dimethylquinolin2(1H)-one (53) to give the corresponding sulfonamides 28-33 (Table 3). These sulfonyl chlorides were selected based on previous beneficial SAR and extrapolation to close analogues. Compounds 28-33 were all found to bind to BRPF1 with strong affinity as measured by DSF $\left(\Delta T_{\mathrm{m}}>8^{\circ} \mathrm{C}\right)$ and 32 was selected as a representative example from this set for further evaluation based on its excellent potency (BRPF1: $\Delta T_{\mathrm{m}} 12.7^{\circ} \mathrm{C} ; \mathrm{IC} 5012 \mathrm{nM}$ ).

Previously it has been shown that increasing the size of the alkyl groups flanking the quinolinone C2carbonyl would prevent binding to the BRPFs (and other BRDs) by disrupting the key recognition interaction between the carbonyl with Asn708 and the Tyr665 water network. This was most successfully achieved with ethyl groups at both the N1 and C3 positions which produced $\mathbf{3 6}$ as a matched inactive control for $\mathbf{1 5}$. Applying this strategy to lead 16 by the introduction of the N1-Et and 3-Et groups gave 37 which still retained some modest BRPF1 activity (IC50 $250 \mathrm{nM}$ ) (Table 3) with only an 80-fold drop in BRPF1 inhibition so as to be unsuitable as a negative control. This level of BRPF1 activity for $\mathbf{3 7}$ was somewhat surprising to us and difficult to explain based on our current understanding of the binding modes of these inhibitors (cf 16 and 66). Ultimately, this will need to be resolved by the determination of a BRPF1-37 co-crystal structure.

$\mathrm{N}$-Alkyl sulfonamides. The $\mathrm{N}$-alkylation of the sulfonamide was detrimental to BRPF1 activity (Table 4). It was found across several structures that the introduction of a $\mathrm{N}$-Me on the sulfonamide group generally reduced BRPF1 activity by 20 -fold ( 38 vs 9,39 vs 24 ). Applying this approach to 16 gave $N$ Me analogue 40 which also showed a 15-fold reduction in BRPF1 inhibition but $\mathbf{4 0}$ still showed significant BRPF1 inhibition (IC $5052 \mathrm{nM}$ ). Increasing the size of the $\mathrm{N}$-alkyl group to $\mathrm{N}$-Et (41) and $\mathrm{N}$ iPr (42) did reduce further BRPF1 activity by 35 -fold and 50 -fold respectively showing some additional disruption to binding but again not to a level to provide a credible negative control.

Structural insights of $\mathbf{1 6}$ in complex to BRPF1B led us to understand the lower affinity for these $\mathrm{N}$ alkyl analogues for BRPF1. We examined all four molecules crystallized at the asymmetric unit of the orthorhombic crystal form. Overall, the $\mathrm{NH}$ of the sulfonamide group is facing towards the Glu661 
residue of the ZA loop. Distances from the $\mathrm{NH}$ group to the glutamic acid lipophilic side chain or the carboxylic group ranged between $3.6-4.3 \AA$ limiting the space to accommodate bulky substituents (Figure S3). Additionally, Glu661 adopts a closed conformation as a result of a water mediated Hbond interaction with a $S(=0)$ of the sulfonamide group of 16 .

Inactive control. The SARs for a partnered inactive control would suggest that further increasing the size of the 3-alkyl to a 3-iPr (cf 16 vs 18 vs 20 ) in combination with a N1-Et (or N1-iPr) would further reduce the BRPF1 activity. A complementary approach to reduce BRPF activity was by substitution of the $\mathrm{NH}$ of the 6-sulfonamide (cf 16 vs $\mathbf{4 0 - 4 2}$ ). However, these SARs seemed to converge on the addition of two or more larger lipophilic groups at either $\mathrm{N} 1, \mathrm{C} 3$ and/or $\mathrm{SO}_{2} \mathrm{NH}$ positions to completely remove BRPF1 activity; these modifications were likely to yield compounds with minimal similarity to the active partner 16 in terms of chemical structure, molecular and physicochemical properties, and so were not pursued. On balance, compound $36(\mathbf{N l}-\mathbf{1 9 8})^{30}$ represents the best available matched inactive control for both 15 and 16.

Preferred compounds. Completing the evaluation of preferred leads 16 and 32 against BRD1 and BRPF3 showed both compounds had potent activity against all three BRPFs with $\mathbf{1 6}$ having a slight advantage (Table 5). However, 16 showed a clear advantage over 32 when evaluated in the BRD9 and BRD4(BD1) selectivity counter screens. Compound 16 had good selectivity over both BRD9 (160-fold) and BRD4 (1200-fold) in the BROMOscan assay which was also superior to 15. In contrast, 32 had poor selectivity compared to 16 with only 14 -fold over BRD9 and 140-fold over BRD4. NonBET BRD inhibitors need to demonstrate excellent selectivity over BRD4 because of the dominant phenotype of this protein in cellular models and the narrow window of selectivity of 32 over BRD4 activity could potentially confound interpretation of biological results. The low level promiscuous nature of $\mathbf{3 2}$ was further confirmed by a full BRD profile of $\mathbf{3 2}$ by DSF with 6 non-class IV proteins having binding $\Delta T_{m}$ in the range $2-3^{\circ} \mathrm{C}(10 \mu \mathrm{M})$ including several members of the BET family (Table S1). The erosion of selectivity for $\mathbf{3 2}$ was a combination of weaker activity for BRPF1 and increase activity for the other BRDs.

Hence 16 emerged as the superior compound from this set suitable for further evaluation as a potential chemical probe for the BRD of the BRPFs. 
Improved Synthesis of $\mathbf{1 6}$. Once $\mathbf{1 6}$ had been identified as a potentially superior compound, the need for larger amounts of material to support SAR and biological studies prompted the development of an improved synthesis of both 6-amino-1,3-dimethylquinolin-2(1H)-one $(44)^{30}$ and 4-cyano-2methoxybenzenesulfonyl chloride $(65)^{37}$ (Scheme 3). A reliable synthesis of 65 initially proved to be somewhat problematic as, to date, there had been no published preparations for 65 and our original approaches to the synthesis of 65 were flawed. Only the diazotization of 4-amino-3methoxybenzonitrile then treatment with aqueous $\mathrm{SO}_{2}-\mathrm{HCl}$ gave modest yields of $65 .{ }^{38}$

We developed an efficient synthesis of sulfonyl chloride 65 from 4-hydroxy-3-methoxybenzonitrile (61) utilising a thermal Newark-Kwart rearrangement ${ }^{39}(62$ to 63$)$ and then $\mathrm{KOH}$ hydrolysis of the carbamothioate 63 to thiol 64 , followed by a zirconium(IV) chloride promoted oxidative chlorination reaction ${ }^{40}$ as the key steps. ${ }^{37}$ High purity 65 could be obtained by recrystallization from a mixed solvent system of toluene-hexane, however the crude material obtained directly from the reaction was found to be sufficiently pure to form sulfonamides in high yields. Simply filtering the acetonitrile solution of crude $\mathbf{6 5}$ directly from the reaction flask into a second receiving flask containing a solution of amine 44 and DABCO in DMF produced 16 in a good yield comparable to the 2-step process with recrystallized 65. 
Scheme 3: Synthesis of 65 and 16.<smiles>COc1cc(C#N)ccc1O</smiles>

61<smiles>COc1cc(C#N)ccc1S</smiles>

64<smiles>COc1cc(C#N)ccc1OC(=S)N(C)C</smiles>

62<smiles>COc1cc(C#N)ccc1S(=O)(=O)Cl</smiles>

65<smiles>COc1cc(C#N)ccc1SC(=O)N(C)C</smiles>

63

16

Reagents and Conditions: (a) $\mathrm{CIC}(\mathrm{S}) \mathrm{NMe}_{2}\left(1.0 \mathrm{eq}\right.$ ), DABCO (1.05 eq), DMF, $50{ }^{\circ} \mathrm{C}, 4 \mathrm{~h}, 76 \%$; (b) $200{ }^{\circ} \mathrm{C}, 3 \mathrm{~h}, 94 \%$; (c) $\mathrm{KOH}$ (3.0 eq), $\mathrm{MeOH}, 30{ }^{\circ} \mathrm{C}, 12 \mathrm{~h}, 95 \%$; (d) $\mathrm{ZrCl}_{4}\left(1.0\right.$ eq), $30 \% \mathrm{H}_{2} \mathrm{O}_{2}(3.0$ eq), MeCN, $0{ }^{\circ} \mathrm{C}, 0.5$ h, $92 \%$; (e) 6-amino-1,3-dimethylquinolin-2(1H)-one (44) (0.95 eq), DABCO (1.0 eq), DMF, rt, 6 h, $76 \%$. 
Table 2. BRPF1 SAR of the 6-sulfonamide.<smiles>[R]S(=O)(=O)Nc1ccc2c(ccc(=O)n2C)c1</smiles>

$1-5$<smiles>[Y]n1c(=O)ccc2cc(NS(=O)(=O)c3cc[Y]cc3)ccc21</smiles>

$6-9$<smiles>[Y][Y]1ccc(NS(=O)(=O)c2ccc3c(ccc(=O)n3[Y16])c2)cc1</smiles>

10-13

\begin{tabular}{cccc}
\hline Compound & R or X & \multicolumn{2}{c}{ BRPF1 } \\
\cline { 3 - 4 } & & $\begin{array}{c}\Delta T_{\mathrm{m}} \text { shift at } \\
10 \mu \mathrm{M}\left({ }^{\circ} \mathrm{C}\right)\end{array}$ & $\mathrm{IC}_{50}(\mathrm{nM})^{\mathrm{a}}$ \\
\hline $\mathbf{1}$ & $\mathrm{Me}$ & 1.4 & 2200 \\
$\mathbf{2}$ & $\mathrm{Et}$ & 1.8 & 1200 \\
$\mathbf{3}$ & $\mathrm{iPr}$ & 2.2 & 1100 \\
$\mathbf{4}$ & $\mathrm{CPr}$ & 1.9 & 520 \\
$\mathbf{5}$ & $\mathrm{cHex}$ & 3.9 & 380 \\
& & & \\
$\mathbf{6}$ & $\mathrm{H}$ & 5.3 & 65 \\
$\mathbf{7}$ & $2-\mathrm{CN}$ & 2.4 & 430 \\
$\mathbf{8}$ & $3-\mathrm{CN}$ & 4.4 & 56 \\
$\mathbf{9}$ & $4-\mathrm{CN}$ & 5.2 & 43 \\
& & & \\
$\mathbf{1 0}$ & $\mathrm{H}$ & 3.5 & 1000 \\
$\mathbf{1 1}$ & $2-\mathrm{CN}$ & 2.6 & \\
$\mathbf{1 2}$ & $3-\mathrm{CN}$ & 2.3 & 100 \\
$\mathbf{1 3}$ & $4-\mathrm{CN}$ & 3.1 & \\
\hline
\end{tabular}

a BROMOscan BRD IC 50 values are geometric means of two experiments $(n=2)$. Differences of $<2$-fold should not be considered significant. $b$ BRD9, $\Delta T_{\mathrm{m}}(10 \mu \mathrm{M})=3.9^{\circ} \mathrm{C}$. 
Table 3. BRPF1 SAR of substitution on the quinolin-2-one.<smiles>[R]c1c(NS(=O)(=O)c2c[X]:[Y]cc2)c([R])c2c([R])c([R])c(=O)n(C)c2c1[R]</smiles>

14-35<smiles>[Y]Cc1cc2cc(NS(=O)(=O)C3=CC=[Y]#[X]=C3)ccc2n(CC)c1=O</smiles>

36,37

\begin{tabular}{|c|c|c|c|c|}
\hline \multirow[t]{2}{*}{ Compound } & \multirow[t]{2}{*}{$R^{x}$} & \multirow[t]{2}{*}{$\mathrm{X}$} & \multicolumn{2}{|c|}{ BRPF1 } \\
\hline & & & $\begin{array}{l}\Delta T_{\mathrm{m}} \text { shift at } \\
10 \mu \mathrm{M}\left({ }^{\circ} \mathrm{C}\right)\end{array}$ & $\mathrm{IC}_{50}(\mathrm{nM})^{\mathrm{a}}$ \\
\hline 14 & 3-Me & 2-OMe & 10.2 & 9.0 \\
\hline 15 & 3-Me & $4-\mathrm{CN}$ & 9.7 & $7.9^{\mathrm{b}}$ \\
\hline 16 & 3-Me & 2-OMe,4-CN & 12.3 & 3.1 \\
\hline 17 & $3-E t$ & $4-C N$ & 5.6 & 180 \\
\hline 18 & $3-E t$ & 2-OMe,4-CN & 8.0 & 93 \\
\hline 19 & 3-iPr & $4-\mathrm{CN}$ & & 870 \\
\hline 20 & 3-iPr & 2-OMe,4-CN & & 170 \\
\hline 21 & 4-Me & $4-\mathrm{CN}$ & 4.3 & 24 \\
\hline 22 & $5-\mathrm{F}$ & $4-C N$ & 2.7 & \\
\hline 23 & 7-OMe & $\mathrm{H}$ & 6.3 & 29 \\
\hline 24 & 7-OMe & $4-\mathrm{CN}$ & 5.6 & 53 \\
\hline 25 & 7-OEt & $4-\mathrm{CN}$ & & 55 \\
\hline 26 & 7-OiPr & $4-\mathrm{CN}$ & & 39 \\
\hline 27 & $7-\mathrm{F}$ & $4-\mathrm{CN}$ & 3.8 & \\
\hline 28 & 3-Me,7-OMe & $\mathrm{H}$ & 9.4 & 17 \\
\hline 29 & 3-Me,7-OMe & 2-OMe & 11.0 & \\
\hline 30 & 3-Me,7-OMe & $4-\mathrm{CN}$ & 8.8 & 15 \\
\hline 31 & 3-Me,7-OMe & 2-Me,4-CN & 9.9 & \\
\hline 32 & 3-Me,7-OMe & 2-OMe,4-CN & 12.7 & 12 \\
\hline 33 & 3-Me,7-OMe & 2-OEt,4-CN & 9.5 & \\
\hline 34 & 3-Me, 8-F & $4-\mathrm{CN}$ & 7.1 & \\
\hline 35 & 3-Me, 8-F & 2-OMe,4-CN & 6.8 & 12 \\
\hline 36 & & $4-\mathrm{CN}$ & & $>100,000$ \\
\hline 37 & & 2-OMe,4-CN & & 250 \\
\hline
\end{tabular}

a BROMOscan BRD IC 50 values are geometric means of two experiments $(n=2)$. Differences of $<2$-fold should not be considered significant. ${ }^{b} n=4$. 
Table 4. BRPF1 SAR at the $\mathrm{N}$-sulfonamide position.<smiles>[R]c1cc2c(cc1N([R])S(=O)(=O)c1c[X]:[Y]cc1)cc([R])c(=O)n2C</smiles>

$38-42$

\begin{tabular}{cccccr}
\hline Compound & $\mathrm{R}^{\mathrm{N}}$ & $\mathrm{R}^{3}$ or 7 & $\mathrm{X}$ & \multicolumn{2}{c}{ BRPF1 } \\
\cline { 5 - 6 } & & & & $\begin{array}{c}\Delta T_{\mathrm{m}} \text { shift at } \\
10 \mu \mathrm{M}\left({ }^{\circ} \mathrm{C}\right)\end{array}$ & $\mathrm{IC}_{50}(\mathrm{nM})^{\mathrm{a}}$ \\
38 & $\mathrm{Me}$ & $\mathrm{H}$ & $4-\mathrm{CN}$ & 1.8 & 910 \\
39 & $\mathrm{Me}$ & 7-OMe & $4-\mathrm{CN}$ & & 1000 \\
40 & $\mathrm{Me}$ & 3-Me & 2-OMe,4-CN & 7.1 & 52 \\
41 & $\mathrm{Et}$ & 3-Me & 2-OMe,4-CN & & 110 \\
42 & $\mathrm{iPr}$ & 3-Me & 2-OMe,4-CN & & 160 \\
\hline
\end{tabular}

a BROMOscan BRD IC 50 values are geometric means of two experiments $(n=2)$. Differences of $<2$-fold should not be considered significant. 
Table 5:

BRD selectivity profiles of $\mathrm{N}$-methylquinolin-2(1H)-ones

\begin{tabular}{|c|c|c|c|c|c|}
\hline \multirow{2}{*}{ Compound } & \multicolumn{5}{|c|}{$\mathrm{IC}_{50}(\mathrm{nM})^{\mathrm{a}}$} \\
\hline & BRPF1 & $\begin{array}{l}\text { BRPF2 } \\
\text { (BRD1) }\end{array}$ & BRPF3 & BRD9 & BRD4(BD1) \\
\hline 6 & 65 & 1400 & 7600 & 2200 & 1700 \\
\hline 7 & 430 & 1700 & & & \\
\hline 8 & 56 & 270 & & & \\
\hline 9 & 43 & 200 & 1000 & 910 & 2800 \\
\hline 10 & 1000 & 7800 & $>100,000$ & 9800 & 37,000 \\
\hline 13 & 100 & 150 & 2200 & & \\
\hline 14 & 9.0 & 130 & & & 600 \\
\hline 15 & $7.9^{b}$ & 48 & 260 & 310 & 4500 \\
\hline 16 & 3.1 & 46 & 140 & 520 & 3700 \\
\hline 19 & 870 & 14,000 & 16,000 & & \\
\hline 20 & 170 & 3300 & 4600 & 9300 & \\
\hline 21 & 24 & 150 & & & \\
\hline 23 & 29 & 380 & 2200 & & \\
\hline 24 & 53 & 520 & 2200 & 2700 & $>10,000$ \\
\hline 28 & 17 & 190 & 590 & & \\
\hline 30 & 15 & 100 & 280 & & \\
\hline 32 & 12 & 80 & 190 & 170 & 1700 \\
\hline 35 & 12 & 510 & 10,000 & & \\
\hline $36^{c}$ & $>100,000$ & $>100,000$ & $>100,000$ & $>100,000$ & $>100,000$ \\
\hline 37 & 250 & 4400 & 4600 & & \\
\hline 38 & 910 & 6700 & & & \\
\hline
\end{tabular}

a BROMOscan BRD IC 50 values are geometric means of two experiments $(n=2)$. Differences of $<2$-fold should not be considered significant.

${ }^{\mathrm{b}} \mathrm{n}=4$

'BRD7, ATAD2A, ATAD2B, CREBBP, PCAF, BAZ2A, TRIM33, CECR2: BROMOscan BRD IC $50>100,000$ nM. SMARCA2A: IC 50 77,000 nM. See, reference 30. 
Potency and selectivity of $\mathbf{1 6}$. Completing the evaluation of lead compound $\mathbf{1 6}$ against all members of the class IV family of BRDs in the BROMOscan assay identified affinity for BRD7 but was completely selective over the ATAD2s (Table 6; Figure S4). 16 was confirmed as a potent inhibitor of BRPF1 by independent evaluation in an AlphaScreen biochemical assay and with a very similar relative rank order of activities to other screening formats (Table 6). ${ }^{36}$

Compound 16 was screened for BRD binding by DSF against a panel of 47 BRDs and showed excellent selectivity. All activity was confined to the class IV family of BRDs with $\Delta T_{m}<1{ }^{\circ} \mathrm{C}$ stabilization for all non-class IV BRDs except TRIM24 (2.0), CREBBP (1.1) and EP300 (1.1) (Figure 3; Table S1). 16 was also tested for BRD selectivity in the BROMOscan panel of 46 binding assays and showed all potent activity was confined to the class IV family (Table S2). Once again, TRIM24 was identified as the non-class IV BRD with most affinity $\left(\mathrm{IC}_{50} 1600 \mathrm{nM}\right)$ but still with a 500 -fold window of selectivity.

It is important to note that we did not observe any significant binding or inhibition of BRD4 across multiple orthogonal screening platforms (DSF, BROMOscan, AlphaScreen, FP) (Table 6). These results have been independently corroborated by a group at Bayer in a TR-FRET assay. ${ }^{29}$

Compound 16 was then evaluated in a number of assays to establish the broader pharmacological selectivity and biopharmaceutical properties. 16 was screened for off-target pharmacology against a panel of 55 representative GPCRs, ion channels and enzymes (Eurofins, ExpresSProfile) and was found to have minimal inhibition $(<40 \% @ 10 \mu \mathrm{M}) .{ }^{36}$ Any cardiovascular risk was low as 16 showed minimal activity against a panel of 8 cardiac ion channels $(<40 \% @ 30 \mu \mathrm{M})$ (Table S3). 16 has reasonable aqueous solubility and good cell permeability as measured by transit performance in the Caco2 cell line but with some evidence of efflux (Table 6). 16 has good metabolic stability in both MLM and HLM consistent with predicted low clearance, and weak CYP450 enzyme inhibition (Table S4).

ITC data showed that 16 bound the BRD of BRPF1 with a $K_{D}$ of $31 \pm 2 \mathrm{nM}$, BRD1 with a $K_{D}$ of $110 \pm$ $13 \mathrm{nM}$ and BRPF3 with a $\mathrm{K}_{\mathrm{D}}$ of $410 \pm 47 \mathrm{nM}$, whereas binding to BRD9 was weaker (KD $1000 \pm 130$ nM) (Table 6). ${ }^{36}$ These data showed that 16 was more potent for the BRDs of BRPF1/2/3 and slightly more selective over BRD9 than 15. 


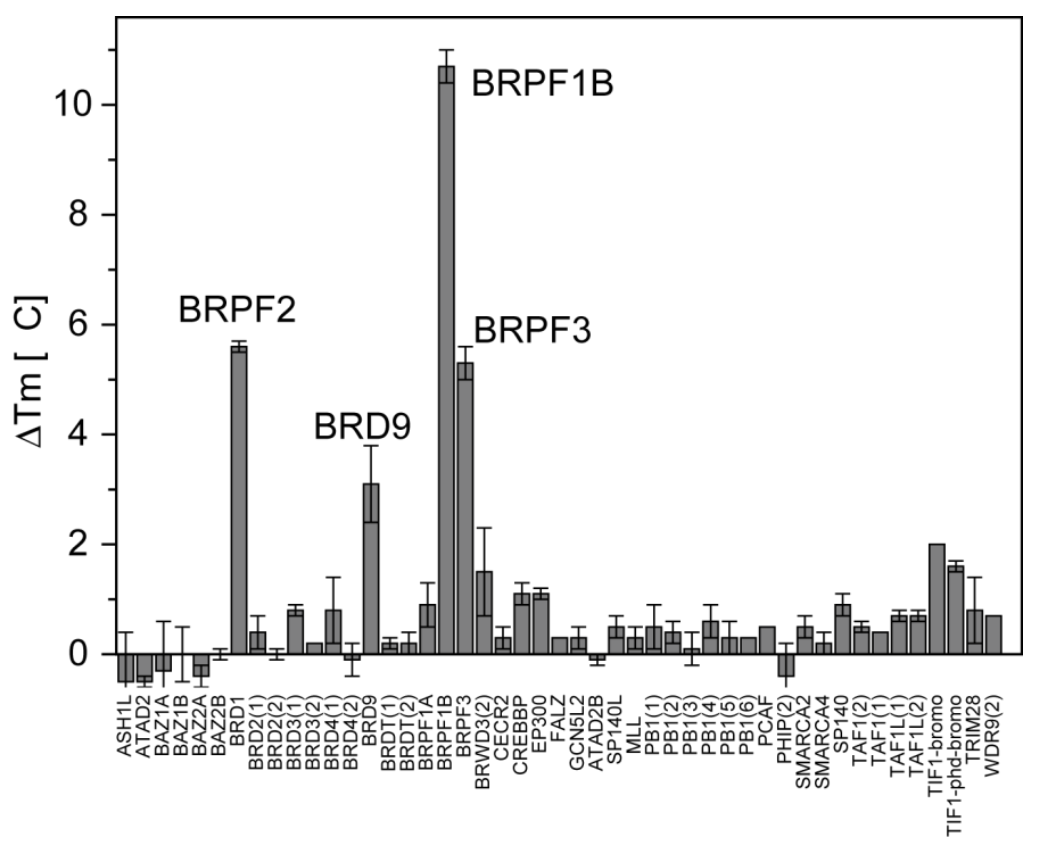

Figure 3. Selectivity profile of 16 assessed against $47 \mathrm{BRDs}$ by thermal shift, $\Delta T_{m}\left({ }^{\circ} \mathrm{C}\right)$, at $10 \mu \mathrm{M}$ as measured by DSF $(n=2)$. 
Table 6: Summary of physicochemical properties, in vitro bromodomain inhibition, ITC screening and cell permeability of $\mathbf{1 6}$.<smiles>COc1cc(C#N)ccc1S(=O)(=O)Nc1ccc2c(c1)cc(C)c(=O)n2C</smiles>

16: NI-57

Physicochemical properties

$\begin{array}{ll}\mathrm{mw} & 383 \\ \mathrm{ClogP} & 2.1 \\ \mathrm{tPSA}\left(\AA^{2}\right) & 99\end{array}$

Bromodomain inhibition

$\begin{array}{llll}\text { BRPF1/2/3 } & \text { BROMOscan } & \text { IC } 50(\mathrm{nM}) & 3.1 ; 46 ; 140 \\ \text { BRD7/9 } & \text { BROMOscan } & \text { IC } 50(\mathrm{nM}) & 140 ; 520 \\ \text { ATAD2A/2B } & \text { BROMOscan } & \text { IC50 }(\mathrm{nM}) & >100,000 ;>100,000 \\ \text { BRD4(BD1) } & \text { BROMOscan } & \text { IC50 (nM) } & 3700 \\ \text { TRIM24 } & \text { BROMOscan } & \text { IC } 50(\mathrm{nM}) & 1600\end{array}$

$\begin{array}{llll}\text { BRPF1/2/3 } & \text { AlphaScreen } & \mathrm{IC}_{50}(\mathrm{nM}) & 114 ; 619 ; 1010^{\mathrm{a}} \\ \text { BRD9 } & \text { AlphaScreen } & \mathrm{IC} 50(\mathrm{nM}) & 4400^{\mathrm{b}} \\ \text { BRD4(BD1) } & \text { AlphaScreen } & \mathrm{IC}_{50}(\mathrm{nM}) & >10,000^{\mathrm{a}} \\ \text { TRIM24 } & \text { AlphaScreen } & \mathrm{IC} 50(\mathrm{nM}) & >10,000^{\mathrm{a}} \\ & & & \\ \text { BRD4(BD1) } & \text { FP assay } & \mathrm{IC}_{50}(\mathrm{nM}) & >33,000^{\mathrm{c}}\end{array}$

Bromodomain ITC screening

$\begin{array}{llll}\text { BRPF1/2/3 } & \text { ITC } & \mathrm{K}_{\mathrm{D}}(\mathrm{nM}) & 31 ; 110 ; 410 \\ \text { BRD9 } & \text { ITC } & \mathrm{K}_{\mathrm{D}}(\mathrm{nM}) & 1000\end{array}$

Solubility and cell permeability

Aqueous solubility

Caco2 transit AB/BA, $P_{\text {app }}\left(\times 10^{-6} \mathrm{cms}^{-1}\right)$

moderate $(100 \mu \mathrm{M} \text { min })^{d}$

$11 / 52$

a See reference 36 .

b This work.

c See Figure S5.

${ }^{d}$ Maximum concentration used in screening assays created by serial dilution of a $100 \mathrm{mM}$ stock solution of 16 in DMSO. 
Evidence of cellular activity. Cellular 'on-target' activity for $\mathbf{1 6}$ was assessed in a BRPF1BHistone3.3 nanoBRET assay which showed dose-dependent displacement of BRPF1B (but not BRPF1A) from Histone $\mathrm{H} 3.3$ with an estimated $\mathrm{IC}_{50}$ of $0.07 \pm 0.0034 \mu \mathrm{M}$. These results were verified in a FRAP assay where $\mathbf{1 6}$ displaced a triple BRD-BRPF1B-GFP fusion construct, as well as full length BRD1-GFP, which was demonstrated by significant reduction in recovery times in the presence of the inhibitor. ${ }^{36}$ Hence, the nanoBRET and FRAP experiments confirm 16 inhibit BRPF BRDs in the nucleus.

Activity in phenotypic screens. BRD containing proteins are frequently dysregulated in cancer. ${ }^{41}$ Previously, compound $\mathbf{1 5}$ has been evaluated in a panel of cancer cell lines and showed a modest inhibition of proliferation of certain AML lines, particularly those lines exhibiting monocytic lineage differentiation. ${ }^{30}$ Here we report additional studies that show 16 has functional activity in cellular assays by modulation of the phenotype (or markers) at low $\mu$ molar concentrations in both cancer and inflammatory models.

Compound 16 was evaluated in two indexed panels of cancer cell lines: the NIH National Cancer Institute $\mathrm{NCl}-60^{42}$ and AstaZeneca's CLIMB panel. ${ }^{43}$ Screening 16 in the $\mathrm{NCl}-60$ panel showed minimal effects on inhibition of proliferation over $48 \mathrm{~h}$ with typically $\leq 25 \%$ inhibition at $10 \mu \mathrm{M}$ in these lines. We subsequently treated the CLIMB panel with 16 for $72 \mathrm{~h}$ and observed modest and selective inhibition of proliferation of certain cell lines (Table 7). It is encouraging that, for these lines, both 15 and 16 show a similar effect on inhibition of proliferation. The different outcomes in the two panel screens are not inconsistent as the responding cell lines in the CLIMB panel were not present in the $\mathrm{NCl}-60$. These results highlight the value of wide profile screening in phenotypical assays in conjunction with hypothesis driven screening strategies. In addition, these BRPF BRD inhibitors 15 and $\mathbf{1 6}$ had minimal effect on the proliferation of many cancer cell lines in the CLIMB panel (and other cell lines) suggesting they are not cytotoxic. ${ }^{30,36}$ 
Table 7. Examples of inhibition of proliferation of cancer cell lines $\left(\mathrm{Gl}_{50}\right)$ by 15 and 16 . $^{\mathrm{a}}$

\begin{tabular}{lllc}
\hline \multirow{2}{*}{ Cancer cell line } & Tissue & \multicolumn{2}{c}{$\mathrm{G}_{50}(\mu \mathrm{M})$} \\
\cline { 4 - 4 } & & $\mathbf{1 5}$ & $\mathbf{1 6}$ \\
\hline $\mathrm{NCl}-\mathrm{H} 1703$ & lung & $>30$ & 10.4 \\
$\mathrm{DMS114}$ & lung & 16.6 & 14.7 \\
$\mathrm{HRA}-19$ & colon & 15.6 & 15.6 \\
RERF-LC-Sq1 & lung & 17.1 & 16.6 \\
$\sim 150$ cell lines & various & b & $>30$ \\
\hline
\end{tabular}

a AstaZeneca CLIMB panel includes 211 cancer cell lines. $72 \mathrm{~h}$ proliferation assay; 9 point dose-response-curve with a highest concentration of 10 or $30 \mu \mathrm{M}(\mathrm{n}=2)$. For an example of the use of oncology cell panels in mechanistic and pathways analysis, see reference 43. $b$ For a more complete profile of $\mathbf{1 5}$ in this panel, see reference 30 .

Small molecule chemical probes that modulate BRD proteins are being employed to reveal the role of epigenetics in guiding cell fate decisions during immune responses and have highlighted the potential of these approaches for the treatment of inflammatory and immune-related disease. ${ }^{44}$ Human macrophages are characterized by their remarkable plasticity and can be skewed towards a proinflammatory phenotype upon LPS/IFNy stimulation $(100 \mathrm{ng} / \mathrm{ml})$, resulting in the production of proinflammatory cytokines such as TNF (Figure 4A). On the opposite end of the macrophage activation spectrum, IL-4 (200ng/ml) induces a Type II inflammation phenotype characterized by the production of CCL-22 (Figure 4A). ${ }^{45,46}$ BRPF1 gene expression was significantly increased in IL-4-stimulated human alveolar macrophages (AM) in comparison to LPS/IFNY-stimulated AM with a $1.7 \pm 0.5$ fold increase (Figure 4B). Blocking BRPF1 in the IL-4-stimulated AM with $16(10 \mu \mathrm{M})$ decreased the gene expression of CCL-22 by $27.7 \pm 9.4 \%$ (Figure 4 C). 

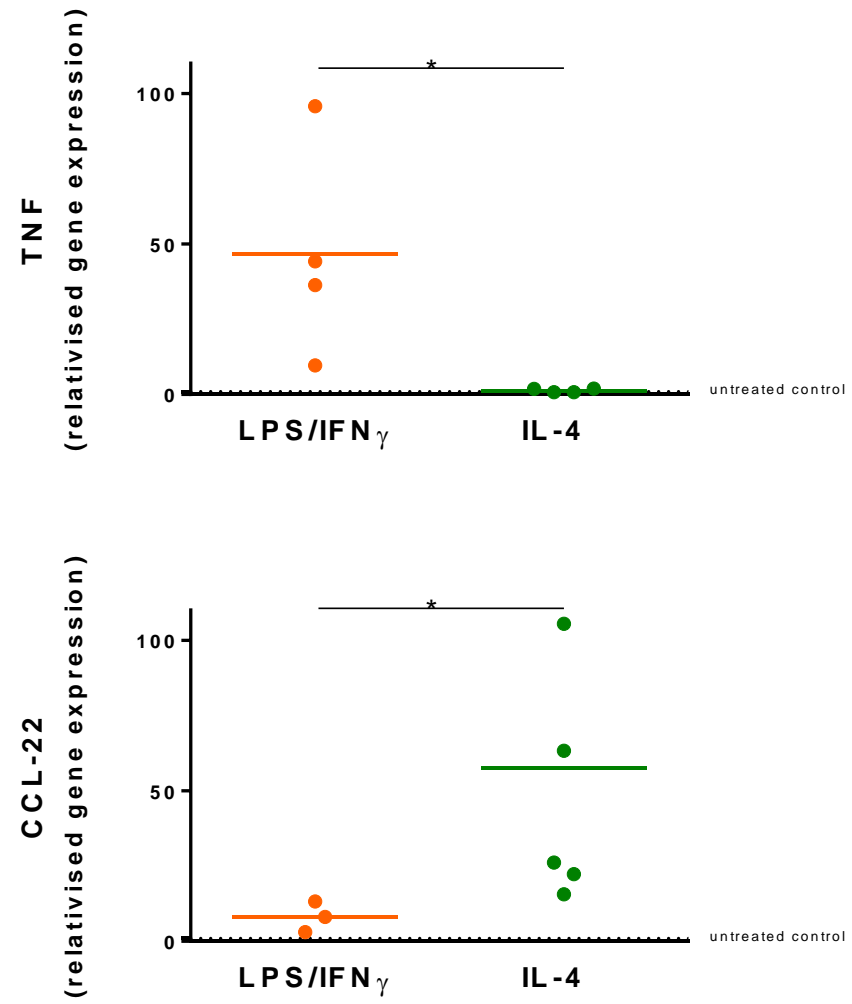

B

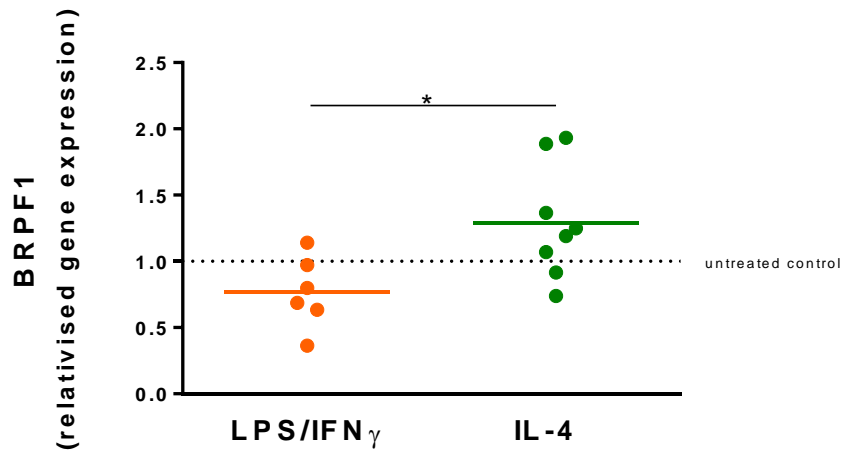

C 


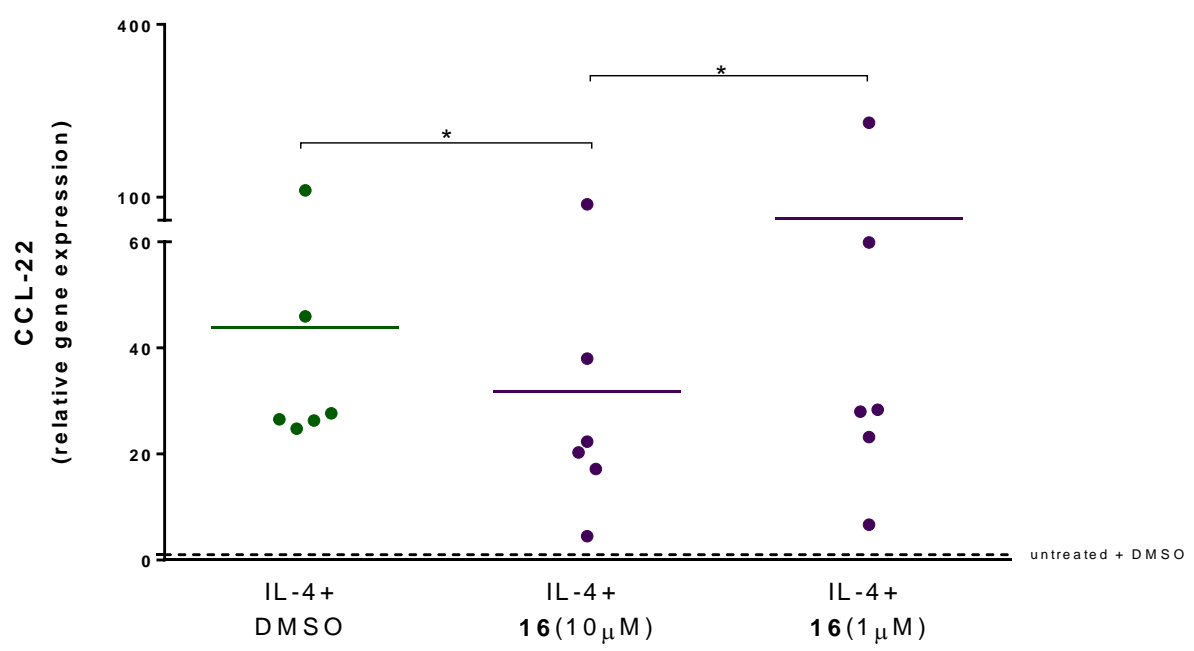

Figure 4. Alveolar Macrophages (AM) were isolated from lung resections of non-smoker, ex-smoker and smoker subjects. Isolated AM were LPS/IFNY-stimulated $(100 \mathrm{ng} / \mathrm{ml})$ or IL-4-stimulated $(200 \mathrm{ng} / \mathrm{ml})$ during $24 \mathrm{~h}$ together with DMSO ( $\bullet$, •, respectively). Subsequently, TNF and CCL-22 (A) or BRPF1 (B) gene expression were measured and plotted. Gene expression was relativised to untreated macrophages. (C) IL-4 stimulated alveolar macrophages were treated with DMSO or $16(\bullet)$ and CCL22 gene expression was measured and plotted. Gene expression was relativised to DMSO treated macrophages. $\left({ }^{*}=p<0.05\right.$, Wilcoxon comparison test)

M2-activated alveolar macrophages have been shown to play a role in the resolution of many lung inflammatory conditions, but can also contribute to different pulmonary diseases. Eosinophilic pneumonia and asthma have been associated with an increased CCL-22 production by alveolar macrophages. ${ }^{47,48}$ The observation that BRPF1 is involved in inducing CCL-22 production by alveolar macrophages could be of importance for the treatment of these pulmonary diseases.

Taken together, these results provide evidence that $\mathbf{1 6}$ is functionally active in cellular assays although we have yet to prove that these effects are the direct consequences of the inhibition of the BRD of the BRPFs. Additional studies will be required to more fully establish the role of $\mathbf{1 6}$ and the BRPFs in cancer and inflammation including demonstration of on-target effects and target confirmation in disease relevant cell models. These studies are ongoing by this group and will be reported in due course.

In an associated Article, we explore functional consequences of inhibitors targeting BRDs present in BRPFs in bone maintenance. We report three complementary potent and selective inhibitors: one with 
high selectivity for the BRPF1B isoform, ${ }^{25}$ and two structurally different pan-BRPF BRD inhibitors. ${ }^{24}$ The inhibitors impaired RANKL-induced differentiation of primary murine bone marrow cells and human primary monocytes into bone resorbing osteoclasts by repressing transcriptional programs. The data suggest a key role of BRPF in regulating gene expression during osteoclastogenesis. These studies will be reported separately. ${ }^{36}$

In vivo Pharmacokinetics. PK data for 16 was generated in vivo in mouse (Table S4). Following single intravenous administration of $\mathbf{1 6}$, clearance was low relative to liver blood flow and volume of distribution was moderate resulting in an elimination half-life of $1.2 \mathrm{~h}$. Single oral administration of 16 as a suspension showed favourable oral bioavailability of $29 \%$. The fraction absorbed was calculated to be $35 \%$ based on the measured blood clearance and oral bioavailability values. 


\section{CONCLUSION}

We have designed and evaluated a number of new quinolin-2-one derivatives as inhibitors of BRPF BRD activity. Previous SARs had identified phenyl sulfonamide 6 as having reasonable binding affinity for all three BRPFs with a preference for BRPF1 (IC $5065 \mathrm{nM})$. This new phase of detailed SAR studies showed that a broader range of substitution of the phenyl ring of the sulfonamide could be accommodated with 4-CN and 2-OMe,4-CN groups preferred. Introduction of groups at each of the available positions on the quinolin-2-one core showed some advantage over hydrogen but failed to improve BRPF1 activity to the same level as had been achieved with a 3-Me substituent (15). The combination of the preferred substituents on the sulfonamide ring with the 1,3-dimethylquinolin-2-one core gave 16 as our most potent BRPF1 inhibitor ( $\left.\mathrm{IC}_{50} 3.1 \mathrm{nM}\right)$. Additional screening of $\mathbf{1 6}$ showed potent binding affinity for all three BRPFs with good selectivity over BRD9 and BRD4. The binding of 16 to BRPF1 was rationalized through an X-ray co-crystal structure determination which showed a flipped binding orientation of the quinolin-2-one in the Ac-Lys pocket when compared to previous structures.

Compound 16 was then evaluated in a number of assays to establish the broader pharmacological selectivity. 16 showed excellent selectivity in panels of BRDs with all potent activity confined to the class IV family of BRDs and minimal off-target pharmacology against a panel of representative GPCRs, ion channels and enzymes. ITC data confirmed that 16 preferentially bound the BRD of BRPF1 and BRD1 over BRPF3 whereas binding to BRD9 was weaker. Based on these results, 16 was identified as a potent inhibitor of the BRD of the BRPFs with excellent selectivity over non-class IV BRD proteins. BRPF1 target engagement in living cells with $\mathbf{1 6}$ was demonstrated in both nanoBRET and FRAP assays.

Evaluation of 16 in a panel of cancer cell lines showed a modest $\left(\mathrm{Gl}_{50} 10-16 \mu \mathrm{M}\right)$ and selective inhibition of proliferation of certain lines. In addition, 16 decreased the expression of M2-associated genes, such as CCL-22, in human alveolar macrophages. These results provide clear evidence that 16 has activity in cellular assays. However, additional studies will be required to fully establish the role of 16 and the BRPFs in disease models. 
Pharmacokinetic data for $\mathbf{1 6}$ was generated in vivo in mouse with single oral administration of $\mathbf{1 6}$ as a suspension showing favourable oral bioavailability. These results established that $\mathbf{1 6}$ had PK properties compatible with oral dosing in mouse models of disease.

In conclusion, we propose that $\mathbf{1 6}$ ( $\mathbf{N I}-\mathbf{5 7})^{36}$ is a new pan-BRPF chemical probe for BRD of the BRPFs suitable for cellular and in vivo studies to explore the fundamental biology of these proteins. Compound 16 has good selectivity over both BRD9 (160-fold) and BRD4 (1200-fold) in the BROMOscan assay which is superior to 15 (39-fold and 570-fold respectively), although the BRD9 selectivity is eroded somewhat in the ITC screen. Ultimately the merits of 15 and 16 will be established by their relative utility in both biochemical assays and performance in phenotypical screens. Preliminary results with these chemical probes in number of cellular models are helping to establish a possible link between the BRPF proteins and disease. 


\section{EXPERIMENTAL SECTION}

\section{Chemistry methods and compound characterization data for 16.}

\section{General Methods:}

All anhydrous solvents and reagents were obtained from commercial suppliers and used without further purification. Flash chromatography refers to medium pressure silica gel (C60 (40-60 $\mu \mathrm{m})$ ) column chromatography, unless otherwise stated. The progress of reactions was monitored by thin layer chromatography (TLC) performed on Keiselgel $60 \mathrm{~F}_{254}$ (Merck) silica plates and visualised by exposure to UV light at $254 \mathrm{~nm}$.

Melting points $(\mathrm{mp})$ were determined in open capillary tubes on a Stuart SMP10 apparatus and are uncorrected. Infrared (IR) analysis was performed on a Perkin Elmer Spectrum 1000 FT-IR in the 4000-400 $\mathrm{cm}^{-1}$ range. ${ }^{1} \mathrm{H}$ Nuclear Magnetic Resonance ( ${ }^{1} \mathrm{H}$ NMR) spectra were recorded on a Bruker Advance 400 Spectrophotometer at $400 \mathrm{MHz}$ or Bruker Advance 500 Spectrophotometer at $500 \mathrm{MHz}$. Chemical shifts were measured in parts per million $(\mathrm{ppm})$ relative to tetramethylsilane $(\delta=0)$ using the following internal references: $\mathrm{CDCl}_{3}(\delta 7.26), \mathrm{CD}_{3} \mathrm{OD}(\delta 3.32)$, DMSO- $d_{6}(\delta 2.50)$. Multiplicities in ${ }^{1} \mathrm{H}$ NMR spectra are quoted as: $\mathrm{s}=$ singlet, $\mathrm{d}=$ doublet, $\mathrm{t}=$ triplet, $\mathrm{q}=$ quartet, $\mathrm{m}=$ multiplet, $\mathrm{dd}=$ double doublet, ddd $=$ double double doublet. ${ }^{13} \mathrm{C}$ Nuclear Magnetic Resonance $\left({ }^{13} \mathrm{C}\right.$ NMR) spectra were recorded on a Bruker Advance 500 Spectrophotometer at $125 \mathrm{MHz}$. Chemical shifts were measured in parts per million (ppm) relative to tetramethylsilane $(\delta=0)$ using the following internal

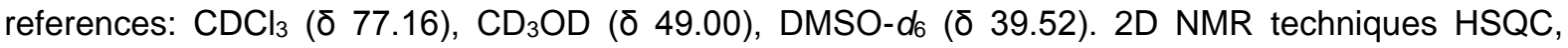
$\mathrm{HMQC}$ and $\mathrm{HMBC}$ were also utilised for the assignment of ${ }^{1} \mathrm{H}$ and ${ }^{13} \mathrm{C}$ NMR signals. High-resolution mass spectra (HRMS) were recorded on a Thermo Navigator mass spectrometer coupled to an HPLC instrument using electrospray ionisation (ESI) and time-of-flight (TOF) mass spectrometry. Alternatively, HRMS were recorded at the EPSRC UK National Mass Spectrometry Facility (NMSF) at Swansea University. Analytical reverse-phase high-performance liquid chromatography (HPLC) was carried out on a XSELECT ${ }^{\mathrm{TM}} \mathrm{CSH}^{\mathrm{TM}} \mathrm{C}$-18 column $(2.5 \mu \mathrm{m} ; 6 \times 50 \mathrm{~mm})$. HPLC experiments (system A) were performed with gradient conditions: initial fixed composition $5 \%$ B to $50 \%$ B over 20 min, then increased to $95 \%$ B over $2 \mathrm{~min}$, held for $2 \mathrm{~min}$ at $95 \% \mathrm{~B}$, then returned to $5 \% \mathrm{~B}$ in $1 \mathrm{~min}$. Total duration of gradient run was 25 min. Eluents used were solvent $A\left(\mathrm{H}_{2} \mathrm{O}\right.$ with $0.02 \%$ TFA) and solvent B (MeCN with $0.02 \%$ TFA). Flow rate: $1.00 \mathrm{~mL} / \mathrm{min}$. 
Purity of screening compounds 1-42 was evaluated by NMR spectroscopy and HPLC analysis. All compounds had purity $\geq 95 \%$ by HPLC.

Compound 16 is commercially available from Tocris (cat no. 5786), Cayman (17662), Sigma-Aldrich (SML-1486) and other suppliers.

\section{4-Cyano- $N$-(1,3-dimethyl-2-oxo-1,2-dihydroquinolin-6-yl)-2-methoxybenzenesuolfonamide (16):}

A $500 \mathrm{~mL}$ round bottom flask A charged with 6-amino-1,3-dimethylquinolin-2(1H)-one $(44)^{30}(3.25 \mathrm{~g}$, $17.3 \mathrm{mmol}, 0.95$ eq.) and 1,4-diazabicyclo[2.2.2]octane (2.10 g, $18.7 \mathrm{mmol}) 1.0 \mathrm{eq}$.) was evacuated and back-filled with nitrogen three times. Anhydrous DMF $(40 \mathrm{~mL})$ was added and the solution stirred until all solids had dissolved.

Separately, a $250 \mathrm{~mL}$ three-necked round bottom flask B fitted with a reflux condenser and internal thermometer was charged with 4-mercapto-3-methoxybenzonitrile $(64)^{37}$ (3.0 g, $18.2 \mathrm{mmol}, 1.0 \mathrm{eq}$.) and zirconium(IV) chloride (4.2 g, $18.2 \mathrm{mmol}, 1.0$ eq.) before being evacuated and back-filled with nitrogen gas three times. Anhydrous acetonitrile $(90 \mathrm{~mL})$ was added by syringe and the reaction mixture stirred until homogeneous. The reaction mixture was cooled to $0{ }^{\circ} \mathrm{C}$ and then hydrogen peroxide (30\% w/w aqueous, $5.4 \mathrm{~mL}, 54.5 \mathrm{mmol}, 3.0$ eq.) was added dropwise keeping the internal temperature below $10^{\circ} \mathrm{C}$. [CAUTION. The reaction is highly exothermic, as such monitoring the internal temperature during the addition of the hydrogen peroxide is important in order to avoid thermal runaway]. During the hydrogen peroxide addition, the solution was noted to become turbid before returning to a homogenous state. The reaction mixture was maintained at $0{ }^{\circ} \mathrm{C}$ and stirred for a further 0.5 hours, during this time a white precipitate was observed to form. Stirring was then stopped and the precipitate was allowed to settle on the bottom of the flask. The freshly formed solution of 4-cyano-2-methoxybenzenesulfonyl chloride (65) in acetonitrile was then transferred by cannula into the stirred DMF solution of $\mathbf{4 4}$ in flask A. During the addition, a white mist was observed to form in the flask that dissipated after about 10 minutes. The remaining solid in the emptied flask $B$ was washed with an additional $20 \mathrm{~mL}$ of anhydrous acetonitrile and the supernatant was again transferred by cannula into the receiving flask $A$. The resultant heterogeneous reaction mixture was stirred for a further 6 hours at room temperature after which time all of $\mathbf{4 4}$ was consumed. The reaction mixture was then poured into a one litre conical flask containing ice-cold hydrochloric acid 
$(1.0 \mathrm{M}, 200 \mathrm{~mL})$ and stirred for 0.5 hours. The off-white precipitate was then collected onto a glass sintered-funnel, washed with two portions of cold ethanol $(50 \mathrm{~mL})$ and dried overnight to give 16 (5.04 g, $76 \%$ ) as an off-white solid. Mp 246-247 ${ }^{\circ} \mathrm{C} ;{ }^{1} \mathrm{H}$ NMR (500 MHz, DMSO-d6): $\delta 10.30$ (s, 1H), 7.86 (d, $J=8.2 \mathrm{~Hz}, 1 \mathrm{H}$ ), 7.74 (d, $J=1.3 \mathrm{~Hz}, 1 \mathrm{H}$ ), 7.70 (s, 1H) 7.47 (dd, $J=7.9,1.3 \mathrm{~Hz}, 1 \mathrm{H}), 7.38$ (d, $J=$ $8.8 \mathrm{~Hz}, 1 \mathrm{H}) 7.31$ (d, J = 2.2 Hz, 1H), 7.26 (dd, J = 7.9, $1.3 \mathrm{~Hz}, 1 \mathrm{H}), 3.98$ (s, 3H), 3.55 (s, 3H), 2.09 (s, $3 \mathrm{H}) ;{ }^{13} \mathrm{C}$ NMR (125 MHz DMSO-d6): $\delta$ 161.3, 156.3, 135.9, 135.0, 131.1, 130.7, 129.9, 124.1, 122.9, 120.2, 119.0, 117.5, 116.8, 116.7, 115.3, 59.6, 29.4, 17.3; HRMS: $m / z$ ESI+ Found $(\mathrm{M}+\mathrm{H})^{+} 384.1013$. $\mathrm{C}_{19} \mathrm{H}_{17} \mathrm{~N}_{3} \mathrm{O}_{4} \mathrm{~S}$ requires $(\mathrm{M}+\mathrm{H})^{+}$384.0940; HPLC: Retention time (system $\mathrm{A}$ ): $\mathrm{t}_{\mathrm{R}}=6.04$ min. Purity: $>95 \%$.

O-(4-Cyano-2-methoxyphenyl) dimethylcarbamothioate (62): To a $500 \mathrm{~mL}$ three-necked round bottom flask fitted with a $100 \mathrm{~mL}$ pressure-equalised dropping funnel and internal thermometer was added 4-hydroxy-3-methoxy-benzonitrile (61) (25.0 g, $168 \mathrm{mmol}, 1.0 \mathrm{eq}$.) followed by 1,4diazabicyclo[2.2.2]octane (19.8 g, 176, 1.05 eq.). The system was next flushed with nitrogen and anhydrous DMF (100 mL) added via syringe. The slurry was warmed to $50{ }^{\circ} \mathrm{C}$ during which time it became an homogenous brown solution. In the interim, a solution of dimethylcarbamoyl chloride (20.7 g, $168 \mathrm{mmol}, 1.0$ eq.) in anhydrous DMF (30 mL) was prepared in a $100 \mathrm{~mL}$ round bottom flask at room temperature and transferred to the dropping funnel. The solution of dimethylcarbamoyl chloride was next added dropwise to the reaction mixture over a period of 10 minutes and the mixture stirred for a further 4 hours at $50^{\circ} \mathrm{C}$. The reaction mixture was next cooled to room temperature and water $(2 \times 75 \mathrm{~mL})$ added via the dropping funnel. After approximately $75 \mathrm{~mL}$ of water had been added, large scale precipitation of the desired product was observed along with a modest $10{ }^{\circ} \mathrm{C}$ exotherm. After all of the water had been added, the resultant slurry was stirred for a further 0.5 hours before the product was collected by filtration onto a sintered-glass funnel. The white crystals were washed with cold water $(2 \times 50 \mathrm{~mL})$ and dried under vacuum. The product was collected to give pure 62 as white crystals $(30.2 \mathrm{~g}, 76 \%)$. Mp 127-128 ${ }^{\circ} \mathrm{C} ;{ }^{1} \mathrm{H}$ NMR $\left(500 \mathrm{MHz}, \mathrm{CDCl}_{3}\right): \delta 7.31$ (d, $\mathrm{J}=$ $8.2 \mathrm{~Hz}, 1 \mathrm{H}), 7.21(\mathrm{~s}, 1 \mathrm{H}), 7.14(\mathrm{~d}, J=8.2 \mathrm{~Hz}, 1 \mathrm{H}), 3.87(\mathrm{~s}, 3 \mathrm{H}), 3.46(\mathrm{~s}, 3 \mathrm{H}), 3.37(\mathrm{~s}, 3 \mathrm{H}) ;{ }^{13} \mathrm{C} \mathrm{NMR}$ (125 MHz, $\left.\mathrm{CDCl}_{3}\right): \delta 186.6,152.2,146.5,125.3,125.2,118.5,115.8,110.5,56.3,43.5,38.9$.

S-(4-Cyano-2-methoxyphenyl)dimethylcarbamothioate (63): To a $250 \mathrm{~mL}$ three-necked round bottom flask fitted with a reflux condenser was added O-(4-cyano-2-methoxyphenyl) 
dimethylcarbamothioate (62) $(29.0 \mathrm{~g}, 115 \mathrm{mmol}, 1.0 \mathrm{eq}$.). The flask was evacuated and back-filled with nitrogen gas three times and then heated at $200{ }^{\circ} \mathrm{C}$ on a DrySyn heating block. After 3 hours the reaction mixture was allowed to cool to around $150^{\circ} \mathrm{C}$ before toluene $(50 \mathrm{~mL})$ was added via syringe. The reaction mixture was allowed to further cool to around $90^{\circ} \mathrm{C}$ and a further portion of toluene (50 $\mathrm{mL}$ ) was added along with a magnetic stir-bar. The reaction mixture was then allowed to cool to room temperature and stirred overnight, during which time the desired product precipitates as colourless crystals. The precipitate was collected by filtration onto a sintered-glass funnel, washed with cold toluene $(2 \times 50 \mathrm{~mL})$ and dried under vacuum to give analytically pure $63(27.2 \mathrm{~g}, 94 \%)$. Mp 150-151 ${ }^{\circ} \mathrm{C}$; ${ }^{1} \mathrm{H}$ NMR $\left(500 \mathrm{MHz}\right.$, DMSO- $\left.d_{6}\right): \delta 7.60(\mathrm{~d}, J=7.8 \mathrm{~Hz}, 1 \mathrm{H}), 7.57(\mathrm{~d}, J=1.8 \mathrm{~Hz}, 1 \mathrm{H}), 7.43(\mathrm{~d}, J=$ 7.8, $1.8 \mathrm{~Hz}, 1 \mathrm{H}), 3.85$ (s, 3H), 3.15-2.83 (br m, 6H); ${ }^{13} \mathrm{C} \mathrm{NMR} \mathrm{(500} \mathrm{MHz,} \mathrm{DMSO-d6):} \delta$ 163.2, 159.4, $138.0,124.3,123.5,118.4,114.9,113.2,56.6,39.5$.

4-Mercapto-3-methoxybenzonitrile (64): To a $250 \mathrm{~mL}$ round bottom flask was charged S-(4-cyano2-methoxyphenyl)dimethylcarbamothioate (63) (15.7 g, $66.8 \mathrm{mmol}, 1.0$ eq.) followed by methanol (100 mL). To the stirred slurry, was added potassium hydroxide flakes $(11.2 \mathrm{~g}, 200 \mathrm{mmol}, 3.0$ eq. portionwise. The reaction was warmed to $30^{\circ} \mathrm{C}$ and stirred for 12 hours. The homogenous reaction mixture was then diluted with ethyl acetate $(200 \mathrm{~mL})$ and acidified to $\mathrm{pH} 2$ with $3.0 \mathrm{M}$ hydrochloric acid. Sufficient water was then added until any salt precipitate had re-dissolved. The phases were separated and the aqueous layer extracted with ethyl acetate $(2 \times 200 \mathrm{~mL})$. The combined organic phases were washed with brine $(300 \mathrm{~mL})$, dried over anhydrous magnesium sulfate and then concentrated under reduced pressure to give $64(10.6 \mathrm{~g}, 96 \%)$ as a slightly pungent off-white solid. Mp 66-67 ${ }^{\circ} \mathrm{C} ;{ }^{1} \mathrm{H}$ NMR $\left(400 \mathrm{MHz}, \mathrm{CDCl}_{3}\right): \delta 7.32(\mathrm{~d}, J=7.8 \mathrm{~Hz}, 1 \mathrm{H}), 7.16(\mathrm{dd}, J=7.8,1.5 \mathrm{~Hz}, 1 \mathrm{H})$, $7.05(\mathrm{~d}, J=1.5 \mathrm{~Hz}, 1 \mathrm{H}), 4.12(\mathrm{~s}, \mathrm{SH}), 3.93(\mathrm{~s}, 3 \mathrm{H}) ;{ }^{13} \mathrm{C} \mathrm{NMR}\left(125 \mathrm{MHz}, \mathrm{CDCl}_{3}\right): \delta$ 154.3, 129.2, 129.0, 125.0, 118.9, 113.0, 109.1, 56.3. 


\section{ASSOCIATED CONTENT}

\section{Supporting Information}

The Supporting Information is available free of charge on the ACS Publications Website at DOI: $x x x x$ Materials and methods: synthetic procedures and characterisation data for compounds 1 - 42; DSF, BROMOscan, AlphaScreen, FP assay and ITC determinations; protein crystallization, data collection and structure solution. Figures: spectroscopic and analytical data; comparison of BRPF1B complex structures for $\mathrm{NI}-57, \mathrm{NI}-48$ and OF-1; asymmetric unit; dose-response-curves in BROMOscan assay; dose-response-curves in FP assay. Tables: DSF thermal shift selectivity values; BROMOscan panel; IonChannelProfiler data; in vitro ADME profile and mouse PK determinations; crystal structure data collection and refinement statistics. Molecular formula strings with data from tables 2-5.

\section{Accession Codes}

Coordinates for the X-ray structures of the bromodomain of BRPF1B co-crystalised with NI-57 (16) (5MYG) have been deposited in the Protein Data Bank. Authors will release the atomic coordinates and experimental data upon article publication.

\section{AUTHOR INFORMATION}

\section{Corresponding Author}

*Phone: +44 (0)20 7679 6971. E.mail: p.fish@ucl.ac.uk

\section{ORCID}

Stefan Knapp: 0000-0001-5995-6494

Paul V. Fish: $\quad$ 0000-0002-2117-2173

\section{Present Address}

For P.V.F.: Alzheimer's Research UK UCL Drug Discovery Institute, The Cruciform Building, University College London, Gower Street, London WC1E 6BT, UK. 


\section{Notes}

The authors declare the following competing financial interest: N.I., E.D.B. and P.V.F. are coinventors on a patent application covering some of these compounds. ${ }^{49}$ It is important to note that compound $\mathbf{1 6}$ has been deliberately excluded from this patent application.

\section{ACKNOWLEDGMENTS}

N.I. is supported by a UCL School of Pharmacy PhD studentship. P.V.F. wishes to thank the UCL School of Pharmacy, UCL Faculty of Life Sciences, and UCL Business for financial support. S.K. is grateful for support from the German cancer network DKTK. We thank Jeremy Hunt, Aimee Allen and the screening team at DiscoverX Corp. for measuring inhibitor $\mathrm{IC}_{50}$ values in the BROMOscan assay, and the AstraZeneca Oncology screening group for evaluation of 15 and 16 in a panel of cancer cell lines (CLIMB panel). A number of HRMS were recorded at the EPSRC UK National Mass Spectrometry Facility (NMSF) at Swansea University, UK.

The SGC is a registered charity (number 1097737) that receives funds from AbbVie, Bayer Pharma

AG, Boehringer Ingelheim, Canada Foundation for Innovation, Eshelman Institute for Innovation, Genome Canada through Ontario Genomics Institute, Innovative Medicines Initiative (EU/EFPIA) [ULTRA-DD grant no. 115766], Janssen, Merck \& Co., Novartis Pharma AG, Ontario Ministry of Economic Development and Innovation, Pfizer, São Paulo Research Foundation-FAPESP, Takeda, and the Wellcome Trust.

\section{ABBREVIATIONS USED}

AM, alveolar macrophages; AML, acute myeloid leukemia; ATAD2, ATPase family, AAA domain containing; BAZ2A, bromodomain adjacent to zinc finger domain protein 2A; BRD4(BD1), bromodomain containing protein 4, first bromodomain; BET, bromodomain and extra terminal domain; BRD, bromodomain containing protein; BRET, bioluminescence resonance energy transfer; BRPF, bromodomain and PHD finger-containing; CLIMB, Cell Lines Indexed for Molecular Biology; CREBBP, CREB-binding protein; CYP450, cytochrome P450; DABCO, 1,4-diazabicyclo[2.2.2]octane; DSF, 
differential scanning fluorimetry; DMF, N,N-dimethyl formamide; EP300, E1A binding protein p300; EAF6, EAS1-associated factor 6; EPC, enhancer of polycomb; FP, fluorescence polarization; FRAP, fluorescence recovery after photobleaching; GPCR, G-protein-coupled receptor; HAT, histone acyl transferase; HLM, human liver microsomes; IFN $\gamma$, interferon gamma; IL-4, interleukin-4; ING, inhibitor of growth family; ITC, isothermal titration calorimetry; LE, ligand efficiency $=1.4\left(-\log I C_{50}\right) /$ number of heavy atoms; LLE, lipophilic ligand efficiency $=\left(-\log I_{50}\right)-c \log P ; L P S$, lipopolysaccharide; MLM, mouse liver microsomes; MYST, MOZ, Ybf2/Sas3, SAS2 and Tip60; PCAF, P300/CBP-associated factor; PHD, plant homeodomain; PK, pharmacokinetic; PWWP, Pro-Trp-Trp-Pro; SAR, structure activity relationship; SMARCA2, SWI/SNF related, matrix associated, actin dependent regulator of chromatin, subfamily A, member 2; TAF1, transcription initiation factor TFIID subunit 1; TNF, tumor necrosis factor; tPSA, topological polar surface area; TR-FRET, time-resolved fluorescence energy transfer; TRIM24, tripartite motif containing 24; WPF, Trp-Pro-Phe. 


\section{REFERENCES}

1. Muller, S.; Filippakopoulos, P.; Knapp, S. Bromodomains as therapeutic targets. Expert Rev. Mol. Med. 2011, 13, e29.

2. Filippakopoulos, P.; Knapp, S. Targeting bromodomains: epigenetic readers of lysine acetylation. Nat. Rev. Drug Discovery 2014, 13, 337-356.

3. Filippakopoulos, P.; Picaud, S.; Mangos, M.; Keates, T.; Lambert, J. P.; Barsyte-Lovejoy, D.; Felletar, I.; Volkmer, R.; Muller, S.; Pawson, T.; Gingras, A. C.; Arrowsmith, C. H.; Knapp, S. Histone recognition and large-scale structural analysis of the human bromodomain family. Cell 2012, 149, 214-231.

4. Vidler, L. R.; Brown, N.; Knapp, S.; Hoelder, S. Druggability analysis and structural classification of bromodomain acetyl-lysine binding sites. J. Med. Chem. 2012, 55, 73467359.

5. (a) Knapp, S.; Weinmann, H. Small-molecule modulators for epigenetics targets. ChemMedChem 2013, 8, 1885-1891. (b) Theodoulou, N.H.; Tomkinson, N.C.; Prinjha, R.K.; Humphreys, P.G. Progress in the development of non-BET bromodomain chemical probes. ChemMedChem 2016, 11, 477-487. (c) Romero, F.A.; Taylor, A.M.; Crawford, T.D.; Tsui, V.; Côté, A.; Magnuson, S. Disrupting acetyl-lysine recognition: progress in the development of bromodomain Inhibitors. J. Med. Chem. 2016, 59, 1271-1298. (d) Zhang, G.; Smith, S. G.; Zhou, M.-M. Discovery of chemical inhibitors of human bromodomains. Chem. Rev. (Washington, DC, U.S.) 2015, 115, 11625-11668. (e) Brand, M.; Measures, A. M.; Wilson, B. G.; Cortopassi, W. A.; Alexander, R.; Höss, M.; Hewings, D. S.; Rooney, T. P. C.; Paton, R. S.; Conway, S. J. Small molecule inhibitors of bromodomain-acetyl-lysine Interactions. ACS Chem. Biol. 2015, 10, 22-39. (f) Galdeano, C.; Ciulli, A. Selectivity on-target of bromodomain chemical probes by structure guided medicinal chemistry and chemical biology. Future Med. Chem. 2016, 8, 1655-1680.

6. Filippakopoulos, P.; Qi, J.; Picaud, S.; Shen, Y.; Smith, W. B.; Fedorov, O.; Morse, E. M.; Keates, T.; Hickman, T. T.; Felletar, I.; Philpott, M.; Munro, S.; McKeown, M. R.; Wang, Y.; Christie, A. L.; West, N.; Cameron, M. J.; Schwartz, B.; Heightman, T. D.; La Thangue, N.; French, C. A.; Wiest, O.; Kung, A. L.; Knapp, S.; Bradner, J. E. Selective inhibition of BET bromodomains. Nature 2010, 468, 1067-1073. 
7. Picaud, S.; Wells, C.; Felletar, I.; Brotherton, D.; Martin, S.; Savitsky, P.; Diez-Dacal, B.; Philpott, M.; Bountra, C.; Lingard, H.; Fedorov, O.; Muller, S.; Brennan, P. E.; Knapp, S.; Filippakopoulos, P. RVX-208, an inhibitor of BET transcriptional regulators with selectivity for the second bromodomain. Proc. Natl. Acad. Sci. U.S.A. 2013, 110, 19754-19759.

8. (a) Picaud, S.; Da Costa, D.; Thanasopoulou, A.; Filippakopoulos, P.; Fish, P. V.; Philpott, M.; Fedorov, O.; Brennan, P.; Bunnage, M. E.; Owen, D. R.; Bradner, J. E.; Taniere, P.; O'Sullivan, B.; Muller, S.; Schwaller, J.; Stankovic, T.; Knapp, S. PFI-1, a highly selective protein interaction inhibitor, targeting BET Bromodomains. Cancer Res. 2013, 73, 3336-3346. (b) Fish, P.V.; Filippakopoulos, P.; Bish, G.; Brennan, P.E.; Bunnage, M.E.; Cook, A.S.; Federov, O.; Gerstenberger, B.S.; Jones, H.; Knapp, S.; Marsden, B.; Nocka, K.; Owen, D.R.; Philpott, M.; Picaud, S.; Primiano, M.J.; Ralph, M.J.; Sciammetta, N.; Trzupek, J.D. Identification of a chemical probe for bromo and extra C-terminal bromodomain inhibition through optimization of a fragment-derived hit. J. Med. Chem. 2012, 55, 9831-9837.

9. Nicodeme, E.; Jeffrey, K. L.; Schaefer, U.; Beinke, S.; Dewell, S.; Chung, C. W.; Chandwani, R.; Marazzi, I.; Wilson, P.; Coste, H.; White, J.; Kirilovsky, J.; Rice, C. M.; Lora, J. M.; Prinjha, R. K.; Lee, K.; Tarakhovsky, A. Suppression of inflammation by a synthetic histone mimic. Nature 2010, 468, 1119-1123.

10. Dawson, M. A.; Prinjha, R. K.; Dittmann, A.; Giotopoulos, G.; Bantscheff, M.; Chan, W. I.; Robson, S. C.; Chung, C. W.; Hopf, C.; Savitski, M. M.; Huthmacher, C.; Gudgin, E.; Lugo, D.; Beinke, S.; Chapman, T. D.; Roberts, E. J.; Soden, P. E.; Auger, K. R.; Mirguet, O.; Doehner, K.; Delwel, R.; Burnett, A. K.; Jeffrey, P.; Drewes, G.; Lee, K.; Huntly, B. J.; Kouzarides, T. Inhibition of BET recruitment to chromatin as an effective treatment for MLL-fusion leukaemia. Nature 2011, 478, 529-533.

11. Theodoulou, N. H.; Tomkinson, N. C.; Prinjha, R. K.; Humphreys, P. G. Clinical progress and pharmacology of small molecule bromodomain inhibitors. Curr. Opin. Chem. Biol. 2016, 33, $58-66$.

12. Chen, P.; Chaikuad, A.; Bamborough, P.; Bantscheff, M.; Bountra, C.; Chung, C. W.; Fedorov, O.; Grandi, P.; Jung, D.; Lesniak, R.; Lindon, M.; Muller, S.; Philpott, M.; Prinjha, R.; Rogers, C.; Selenski, C.; Tallant, C.; Werner, T.; Willson, T. M.; Knapp, S.; Drewry, D. H. Discovery 
and characterization of GSK2801, a selective chemical probe for the bromodomains BAZ2A and BAZ2B. J. Med. Chem. 2015, 59, 1410-1424.

13. Drouin, L.; McGrath, S.; Vidler, L. R.; Chaikuad, A.; Monteiro, O.; Tallant, C.; Philpott, M.; Rogers, C.; Fedorov, O.; Liu, M.; Akhtar, W.; Hayes, A.; Raynaud, F.; Muller, S.; Knapp, S.; Hoelder, S. Structure enabled design of BAZ2-ICR, a chemical probe targeting the bromodomains of BAZ2A and BAZ2B. J. Med. Chem. 2015, 58, 2553-2559.

14. Taylor, A. M.; Cote, A.; Hewitt, M. C.; Pastor, R.; Leblanc, Y.; Nasveschuk, C. G.; Romero, F. A.; Crawford, T. D.; Cantone, N.; Jayaram, H.; Setser, J.; Murray, J.; Beresini, M. H.; de Leon Boenig, G.; Chen, Z.; Conery, A. R.; Cummings, R. T.; Dakin, L. A.; Flynn, E. M.; Huang, O. W.; Kaufman, S.; Keller, P. J.; Kiefer, J. R.; Lai, T.; Li, Y.; Liao, J.; Liu, W.; Lu, H.; Pardo, E.; Tsui, V.; Wang, J.; Wang, Y.; Xu, Z.; Yan, F.; Yu, D.; Zawadzke, L.; Zhu, X.; Zhu, X.; Sims, R. J., 3rd; Cochran, A. G.; Bellon, S.; Audia, J. E.; Magnuson, S.; Albrecht, B. K. Fragmentbased discovery of a selective and cell-active benzodiazepinone CBP/EP300 bromodomain inhibitor (CPI-637). ACS Med. Chem. Lett. 2016, 7, 531-536.

15. Popp, T. A.; Tallant, C.; Rogers, C.; Fedorov, O.; Brennan, P. E.; Muller, S.; Knapp, S.; Bracher, F. Development of selective CBP/P300 benzoxazepine bromodomain inhibitors. J. Med. Chem. 2016, 59, 8889-8912.

16. Picaud, S.; Fedorov, O.; Thanasopoulou, A.; Leonards, K.; Jones, K.; Meier, J.; Olzscha, H.; Monteiro, O.; Martin, S.; Philpott, M.; Tumber, A.; Filippakopoulos, P.; Yapp, C.; Wells, C.; Che, K. H.; Bannister, A.; Robson, S.; Kumar, U.; Parr, N.; Lee, K.; Lugo, D.; Jeffrey, P.; Taylor, S.; Vecellio, M. L.; Bountra, C.; Brennan, P. E.; O'Mahony, A.; Velichko, S.; Muller, S.; Hay, D.; Daniels, D. L.; Urh, M.; La Thangue, N. B.; Kouzarides, T.; Prinjha, R.; Schwaller, J.; Knapp, S. Generation of a selective small molecule inhibitor of the CBP/p300 bromodomain for leukemia therapy. Cancer Res. 2015, 75, 5106-5119.

17. Fedorov, O.; Castex, J.; Tallant, C.; Owen, D. R.; Martin, S.; Aldeghi, M.; Monteiro, O.; Filippakopoulos, P.; Picaud, S.; Trzupek, J. D.; Gerstenberger, B. S.; Bountra, C.; Willmann, D.; Wells, C.; Philpott, M.; Rogers, C.; Biggin, P. C.; Brennan, P. E.; Bunnage, M. E.; Schule, R.; Gunther, T.; Knapp, S.; Muller, S. Selective targeting of the BRG/PB1 bromodomains impairs embryonic and trophoblast stem cell maintenance. Sci. Adv. 2015, 1, e1500723. 
18. Myrianthopoulos, V.; Gaboriaud-Kolar, N.; Tallant, C.; Hall, M. L.; Grigoriou, S.; Brownlee, P. M.; Fedorov, O.; Rogers, C.; Heidenreich, D.; Wanior, M.; Drosos, N.; Mexia, N.; Savitsky, P.; Bagratuni, T.; Kastritis, E.; Terpos, E.; Filippakopoulos, P.; Muller, S.; Skaltsounis, A. L.; Downs, J. A.; Knapp, S.; Mikros, E. Discovery and optimization of a selective ligand for the Switch/Sucrose Nonfermenting-Related bromodomains of Polybromo Protein-1 by the use of virtual screening and hydration analysis. J. Med. Chem. 2016, 59, 8787-8803.

19. Clark, P. G.; Vieira, L. C.; Tallant, C.; Fedorov, O.; Singleton, D. C.; Rogers, C. M.; Monteiro, O. P.; Bennett, J. M.; Baronio, R.; Muller, S.; Daniels, D. L.; Mendez, J.; Knapp, S.; Brennan, P. E.; Dixon, D. J. LP99: discovery and synthesis of the first selective BRD7/9 bromodomain inhibitor. Angew. Chem., Int. Ed. 2015, 54, 6217-6221.

20. Martin, L. J.; Koegl, M.; Bader, G.; Cockcroft, X. L.; Fedorov, O.; Fiegen, D.; Gerstberger, T.; Hofmann, M. H.; Hohmann, A. F.; Kessler, D.; Knapp, S.; Knesl, P.; Kornigg, S.; Muller, S.; Nar, H.; Rogers, C.; Rumpel, K.; Schaaf, O.; Steurer, S.; Tallant, C.; Vakoc, C. R.; Zeeb, M.; Zoephel, A.; Pearson, M.; Boehmelt, G.; McConnell, D. Structure-based design of an in vivo active selective BRD9 inhibitor. J. Med. Chem. 2016, 59, 4462-4475.

21. Moustakim, M.; Clark, P. G.; Trulli, L.; Fuentes de Arriba, A. L.; Ehebauer, M. T.; Chaikuad, A.; Murphy, E. J.; Mendez-Johnson, J.; Daniels, D.; Hou, C. D.; Lin, Y. H.; Walker, J. R.; Hui, R.; Yang, H.; Dorrell, L.; Rogers, C. M.; Monteiro, O. P.; Fedorov, O.; Huber, K. V.; Knapp, S.; Heer, J.; Dixon, D. J.; Brennan, P. E. Discovery of a PCAF bromodomain chemical probe. Angew. Chem., Int. Ed. 2017, 56, 827-831.

22. Bamborough, P.; Chung, C. W.; Demont, E. H.; Furze, R. C.; Bannister, A. J.; Che, K. H.; Diallo, H.; Douault, C.; Grandi, P.; Kouzarides, T.; Michon, A. M.; Mitchell, D. J.; Prinjha, R. K.; Rau, C.; Robson, S.; Sheppard, R. J.; Upton, R.; Watson, R. J. A chemical probe for the ATAD2 bromodomain. Angew. Chem., Int. Ed. 2016, 55, 11382-11386.

23. Picaud, S.; Leonards, K.; Lambert, J. P.; Dovey, O.; Wells, C.; Fedorov, O.; Monteiro, O.; Fujisawa, T.; Wang, C. Y.; Lingard, H.; Tallant, C.; Nikbin, N.; Guetzoyan, L.; Ingham, R.; Ley, S. V.; Brennan, P.; Muller, S.; Samsonova, A.; Gingras, A. C.; Schwaller, J.; Vassiliou, G.; Knapp, S.; Filippakopoulos, P. Promiscuous targeting of bromodomains by bromosporine identifies BET proteins as master regulators of primary transcription response in leukemia. Sci. Adv. 2016, 2, e1600760. 
24. OF-1. A chemical probe for the BRPF bromodomains. http://www.thesgc.org/chemicalprobes/OF-1 (accessed February 10, 2017).

25. PFI-4. A chemical probe for BRPF1B. http://www.thesgc.org/chemical-probes/PFI-4 (accessed February 10, 2017).

26. Bamborough, P.; Barnett, H.A.; Becher, I.; Bird, M.J.; Chung, C.W.; Craggs, P.D.; Demont, E.H.; Diallo, H.; Fallon, D.J;. Gordon, L.J.; Grandi, P.; Hobbs, C.I.; Hooper-Greenhill, E.; Jones, E.J.; Law, R.P.; Le Gall, A.; Lugo, D.; Michon, A.M.; Mitchell, D.J.; Prinjha, R.K.; Sheppard, R.J.; Watson, A.J.; Watson, R.J. GSK6853, a chemical probe for inhibition of the BRPF1 bromodomain. ACS Med. Chem. Lett. 2016, 7, 552-557.

27. Palmer, W.S.; Poncet-Montange, G.; Liu, G.; Petrocchi, A.; Reyna, N.; Subramanian, G.; Theroff, J.; Yau, A.; Kost-Alimova, M.; Bardenhagen, J.P.; Leo, E.; Shepard, H.E.; Tieu, T.N.; Shi, X.; Zhan, Y.; Zhao, S.; Barton, M.C.; Draetta, G.; Toniatti, C.; Jones, P.; Geck Do, M.; Andersen, J.N. Structure-guided design of IACS-9571, a selective high-affinity dual TRIM24BRPF1 bromodomain inhibitor. J. Med. Chem. 2016, 59, 1440-1454.

28. Bennett, J.; Fedorov, O.; Tallant, C.; Monteiro, O.; Meier, J.; Gamble, V.; Savitsky, P.; NunezAlonso, G.A.; Haendler, B.; Rogers, C.; Brennan, P.E.; Müller, S.; Knapp, S. Discovery of a chemical tool inhibitor targeting the bromodomains of TRIM24 and BRPF. J. Med. Chem. 2016, 59, 1642-1647.

29. Bouché, L.; Christ, C. D.; Siegel, S.; Fernández-Montalván, A. E.; Holton, S. J.; Fedorov, O.; ter Laak, A.; Sugawara, T.; Stöckigt, D.; Tallant, C.; Bennett, J.; Monteiro, O.; Díaz-Sáez, L.; Siejka, P.; Meier, J.; Pütter, V.; Weiske, J.; Müller, S.; Huber, K. V. M.; Hartung, I. V.; Haendler, B. Benzoisoquinolinediones as Potent and Selective Inhibitors of BRPF2 and TAF1/TAF1L Bromodomains. J. Med. Chem., 2017, 60, 4002-4022.

30. Igoe, N.; Bayle, E. D.; Fedorov, O.; Tallant, C.; Savitsky, P.; Rogers, C.; Owen, D. R. ; Deb, G.; Somervaille, T. C. P.; Andrews, D. M.; Jones, N.; Cheasty, A.; Ryder, H.; Brennan, P. E.; Muller, S.; Knapp, S.; Fish, P. V. Design of a biased potent small molecule inhibitor of the Bromodomain and PHD Finger-containing (BRPF) proteins suitable for cellular and in vivo studies. J. Med. Chem. 2017, 60, 668-680. 
31. Vezzoli, A.; Bonadies, N.; Allen, M. D.; Freund, S. M.; Santiveri, C. M.; Kvinlaug, B. T.; Huntly, B. J.; Gottgens, B.; Bycroft, M. Molecular basis of histone H3K36me3 recognition by the PWWP domain of Brpf1. Nat. Struct. Mol. Biol. 2010, 17, 617-619.

32. (a) Lubula, M. Y.; Eckenroth, B. E.; Carlson, S.; Poplawski, A.; Chruszcz, M.; Glass, K. C. Structural insights into recognition of acetylated histone ligands by the BRPF1 bromodomain. FEBS Lett. 2014, 588, 3844-3854. (b) Lloyd, J. T.; Glass, K. C. Biological function and histone recognition of family IV bromodomain-containing proteins. J. Cell. Physiol. 2017 doi: 10.1002/jcp.26010 (Epub ahead of print).

33. Ullah, M.; Pelletier, N.; Xiao, L.; Zhao, S. P.; Wang, K.; Degerny, C.; Tahmasebi, S.; Cayrou, C.; Doyon, Y.; Goh, S. L.; Champagne, N.; Côté, J.; Yang, X. J. Molecular architecture of quartet MOZ/MORF histone acetyltransferase complexes. Mol. Cell Biol. 2008, 28, 68286843.

34. Lalonde, M. E.; Avvakumov, N.; Glass, K. C.; Joncas, F. H.; Saksouk, N.; Holliday, M.; Paquet, E.; Yan, K.; Tong, Q.; Klein, B. J.; Tan, S.; Yang, X. J.; Kutateladze, T. G.; Cote, J. Exchange of associated factors directs a switch in HBO1 acetyltransferase histone tail specificity. Genes Dev. 2013, 27, 2009-2024.

35. Mishima, Y.; Miyagi, S.; Saraya, A.; Negishi, M.; Endoh, M.; Endo, T. A.; Toyoda, T.; Shinga, J.; Katsumoto, T.; Chiba, T.; Yamaguchi, N.; Kitabayashi, I.; Koseki, H.; Iwama, A. The Hbo1Brd1/Brpf2 complex is responsible for global acetylation of H3K14 and required for fetal liver erythropoiesis. Blood 2011, 118, 2443-2453.

36. Meier, J. C.; Tallant, C.; Fedorov, O.; Witwicka, H.; Hwang, S.-Y.; van Stiphout, R. G.; Lambert, J. P.; Rogers, C.; Gerstenberger, B. S.; Fedele, V.; Savitsky,P.; Daniels, D. L.; Owen, D. R.; Fish, P. V.; Igoe, N. M.; Bayle, E. D.; Haendler, B.; Oppermann, U.; Buffa, F.; Brennan, P.; Muller, S.; Gingras, A. C.; Odgren, P. R.; Birnbaum, M. J.; Knapp, S. Selective targeting of Bromodomain-PHD fingers family (BRPF) bromodomains impairs osteoclast differentiation. Unpublished results.

37. Bayle, E. D.; Igoe,N.; Fish, P. V. Preparation of 4-cyano-2-methoxybenzenesulfonyl chloride. Unpublished results.

38. Hogan, P. J.; Cox, B. G. Aqueous Process Chemistry: The preparation of aryl sulfonyl chlorides. Org. Process Res. Dev. 2009, 13, 875-879. 
39. (a) Newman, M. S.; Karnes, H. A. The conversion of phenols to thiophenols via dialkylthiocarbamates J. Org. Chem. 1966, 31, 3980-3984. (b).Kwart, H.; Evans, E. R. The vapor phase rearrangement of thioncarbonates and thioncarbamates J. Org. Chem. 1966, 31, 410-413.

40. Bahrami, K.; Khodaei, M. M.; Soheilizad, M. A novel, practical synthesis of sulfonyl chlorides from thiol and disulfide derivatives. Synlett 2009, 2773-2776.

41. (a) Fujisawa, T.; Filippakopoulos, P. Functions of bromodomain-containing proteins and their roles in homeostasis and cancer. Nat. Rev. Mol. Cell Biol. 2017, 18, 246-262. (b) Shortt, J.; Ott, C. J.; Johnstone, R. W.; Bradner, J. E. A chemical probe toolbox for dissecting the cancer epigenome. Nat. Rev. Cancer 2017, 17, 160-183.

42. NCl-60 human tumor cell lines screen. https://dtp.cancer.gov/discovery_development/nci-60/ (accessed February 9, 2017).

43. Dry, J.R.; Pavey, S.; Pratilas, C.A.; Harbron, C.; Runswick, S.; Hodgson, D.; Chresta, C.; McCormack, R.; Byrne, N.; Cockerill, M.; Graham, A.; Beran, G.; Cassidy, A.; Haggerty, C.; Brown, H.; Ellison, G.; Dering, J.; Taylor, B.S.; Stark, M.; Bonazzi, V.; Ravishankar, S.; Packer, L.; Xing, F.; Solit, D.B.; Finn, R.S.; Rosen, N.; Hayward, N.K.; French, T.; Smith, P.D. Transcriptional pathway signatures predict MEK addiction and response to selumetinib (AZD6244). Cancer Res., 2010, 70, 2264-2273.

44. Tough, D. F.; Tak, P. P.; Tarakhovsky, A.; Prinjha, R. K. Epigenetic drug discovery: breaking through the immune barrier. Nat. Rev. Drug Discovery 2016, 15, 835-853.

45. Martinez, F. O.; Gordon, S. The M1 and M2 paradigm of macrophage activation: time for reassessment. F1000Prime Rep. 2014, 6, 13.

46. Xue, J.; Schmidt, S. V.; Sander, J.; Draffehn, A.; Krebs, W.; Quester, I.; De Nardo, D.; Gohel, T. D.; Emde, M.; Schmidleithner, L.; Ganesan, H.; Nino-Castro, A.; Mallmann, M. R.; Labzin, L.; Theis, H.; Kraut, M.; Beyer, M.; Latz, E.; Freeman, T. C.; Ulas, T.; Schultze, J. L. Transcriptome-based network analysis reveals a spectrum model of human macrophage activation. Immunity 2014, 40, 274-288.

47. Manabe, K.; Nishioka, Y.; Kishi, J.; Inayama, M.; Aono, Y.; Nakamura, Y.; Ogushi, F.; Bando, H.; Tani, K.; Sone, S. Elevation of macrophage-derived chemokine in eosinophilic pneumonia: a role of alveolar macrophages. Int. J. Med. Invest. 2005, 52, 85-92. 
48. Staples, K. J.; Hinks, T. S.; Ward, J. A.; Gunn, V.; Smith, C.; Djukanovic, R. Phenotypic characterization of lung macrophages in asthmatic patients: overexpression of CCL17. J. Allergy Clin. Immunol. 2012, 130, 1404-1412.

49. Fish, P. V.; Igoe, N.; Bayle, E. D. Preparation of Quinolones as Inhibitors of Class IV Bromodomain Proteins for Cancer Therapy. PCT Int. Appl. WO 2016034512 A1, 2016. 


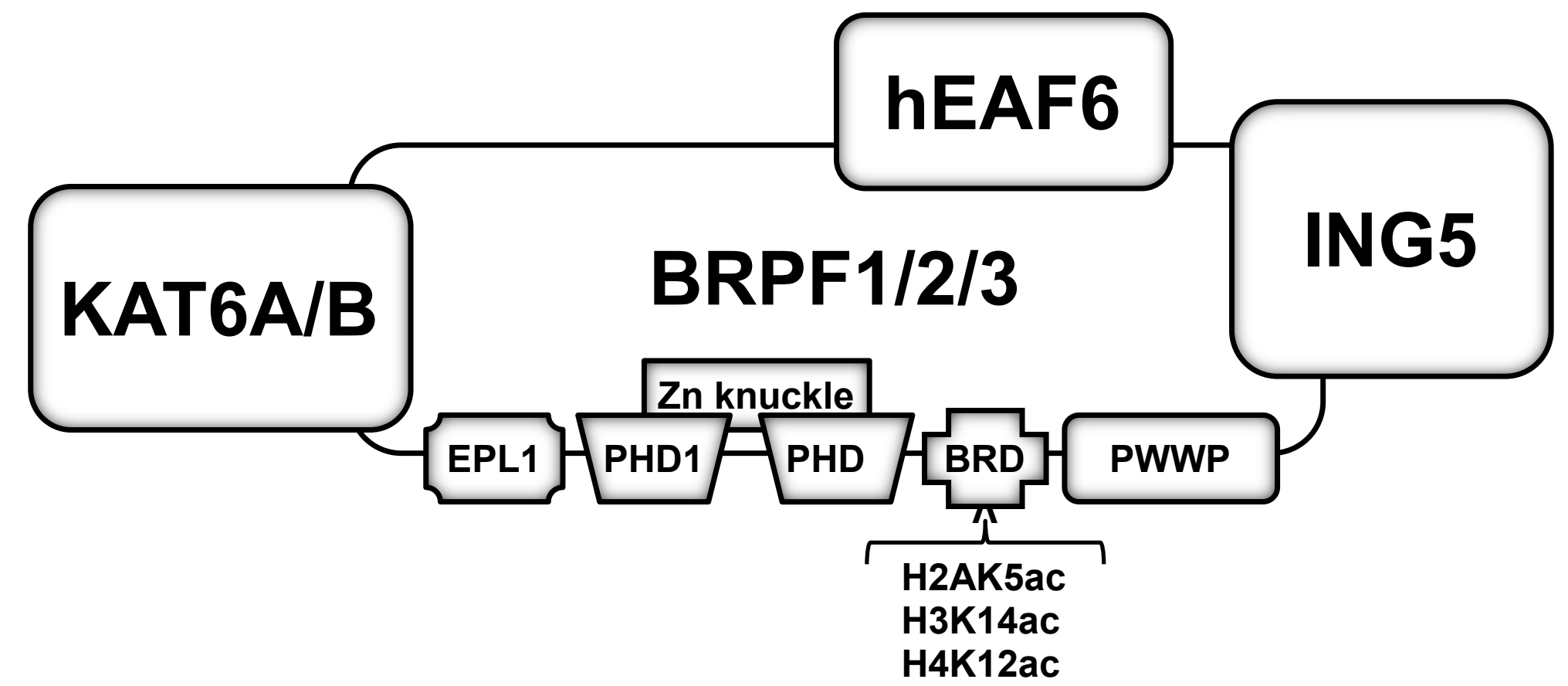

Figure 1. Cartoon representation of BRPFs as part of the tetrameric MYST scaffolding complex along with ING5 and hEAF6. The BRPFs contain multiple chromatin reader domains. 

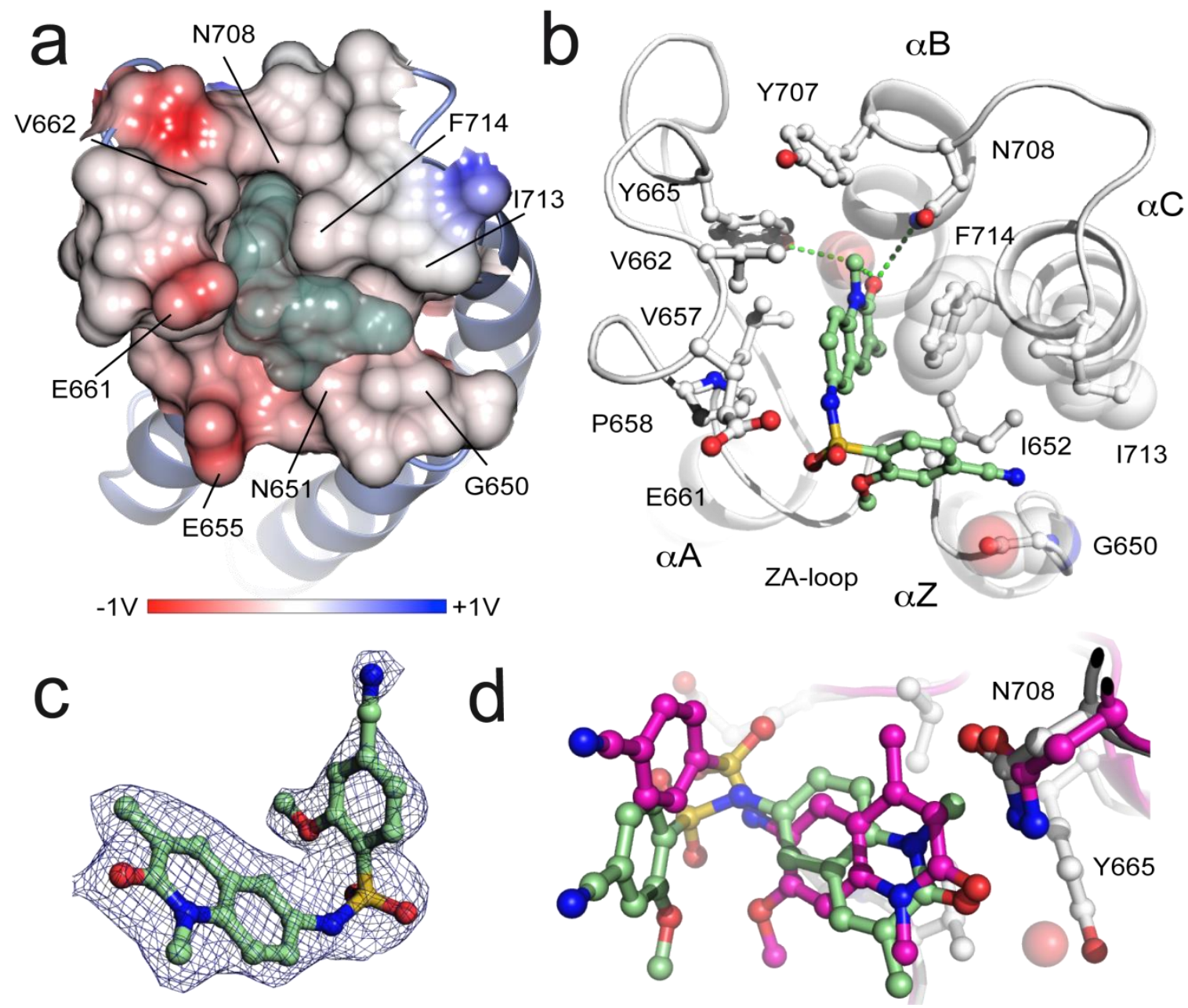

Figure 2. X-ray crystal structure of $\mathbf{1 6}$ (green) bound to BRPF1 (grey) (5MYG.pdb). (a) Electrostatic potential surface represented at the bromodomain binding site. (b) Close-up view of the interactions of 16 with the BRPF1 binding site displayed in cartoon and sticks. (c) 2Fo - Fc electron density map contoured at $1 \sigma$ showing electron density around 16. The figure shows the map for the fully refined structure. (d) Structural superposition of 16 with 66 (purple; 5T4V.pdb) in complex with BRPF1B. 


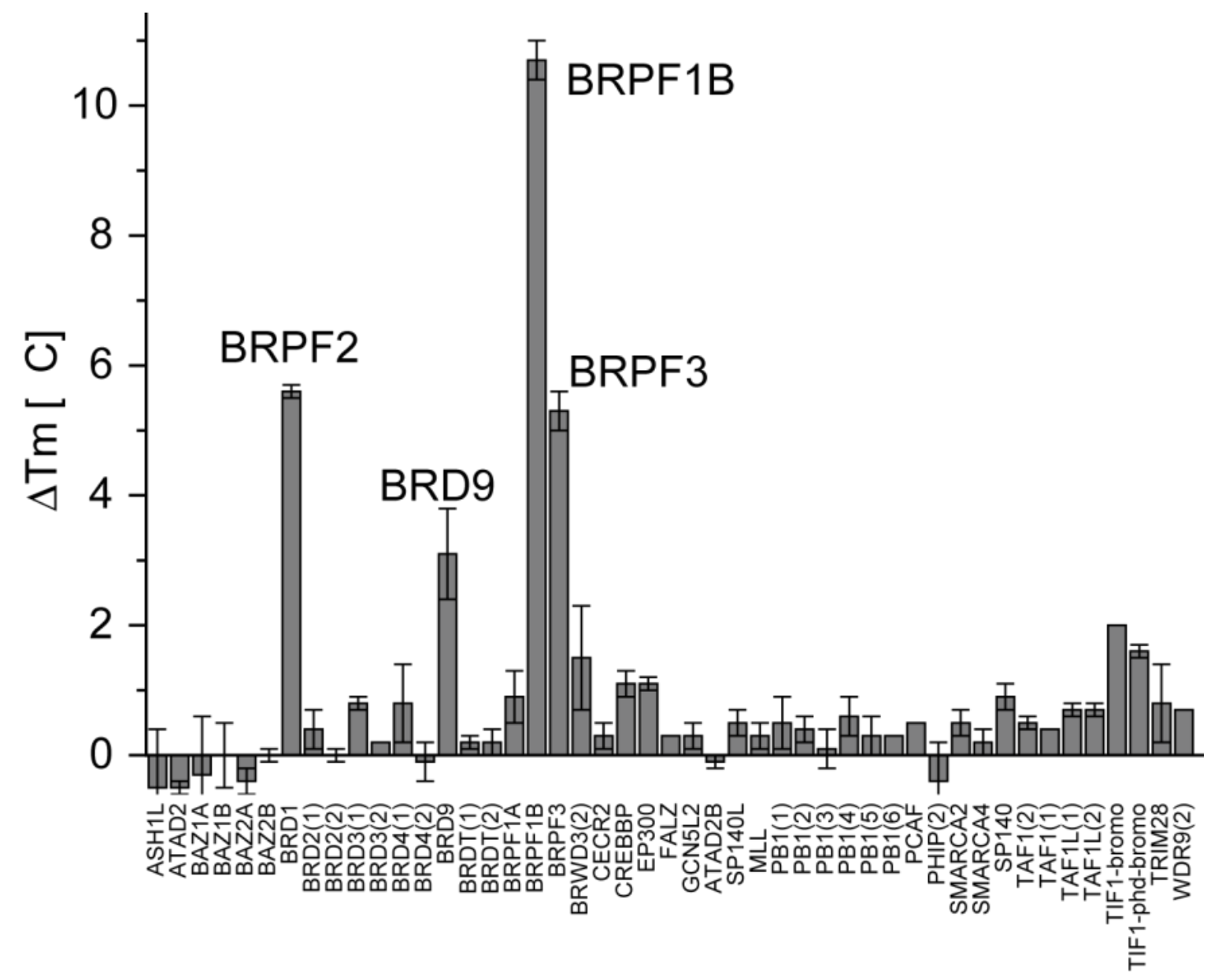

Figure 3. Selectivity profile of 16 assessed against $47 \mathrm{BRDs}$ by thermal shift, $\Delta T_{m}\left({ }^{\circ} \mathrm{C}\right)$, at $10 \mu \mathrm{M}$ as measured by DSF $(n=2)$. 

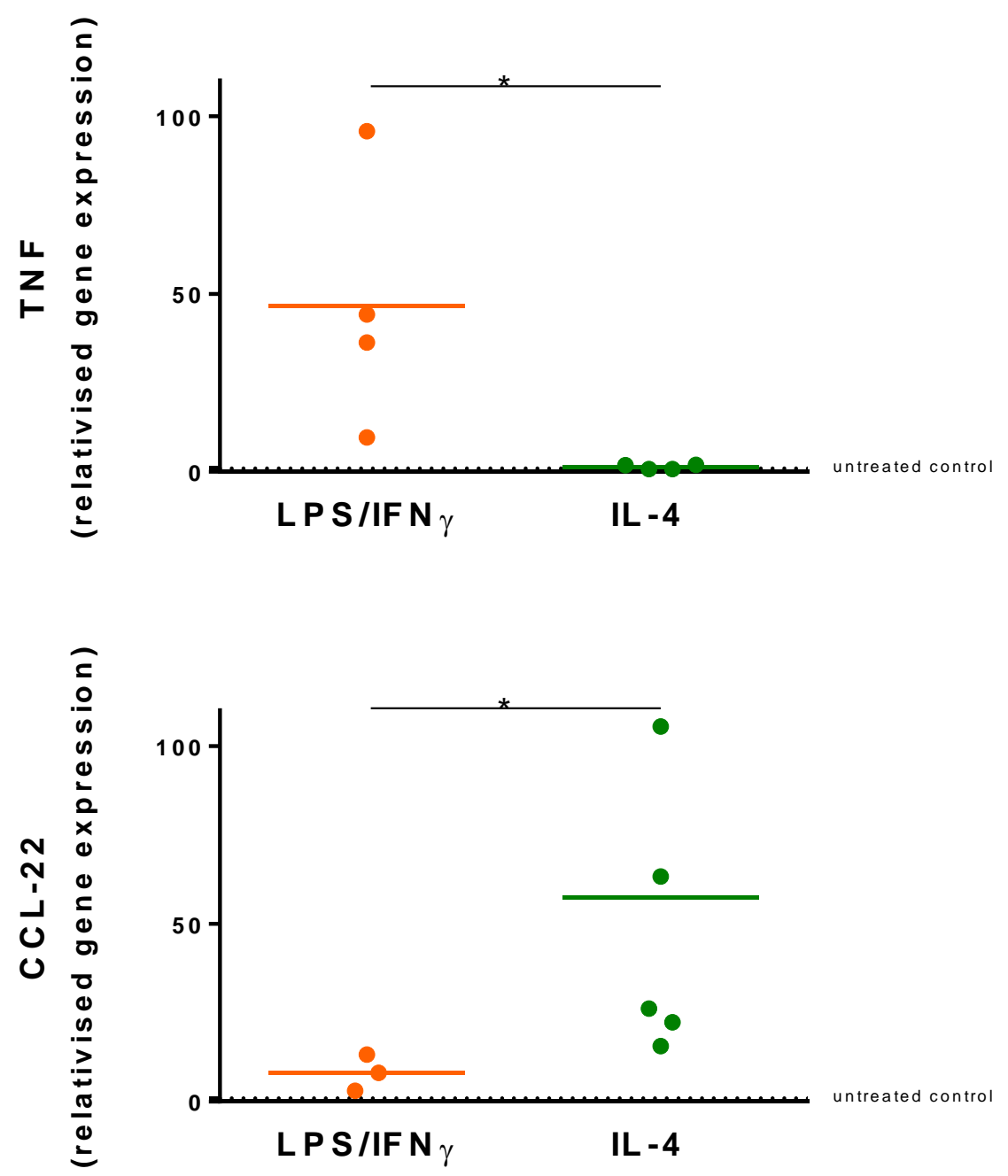

B

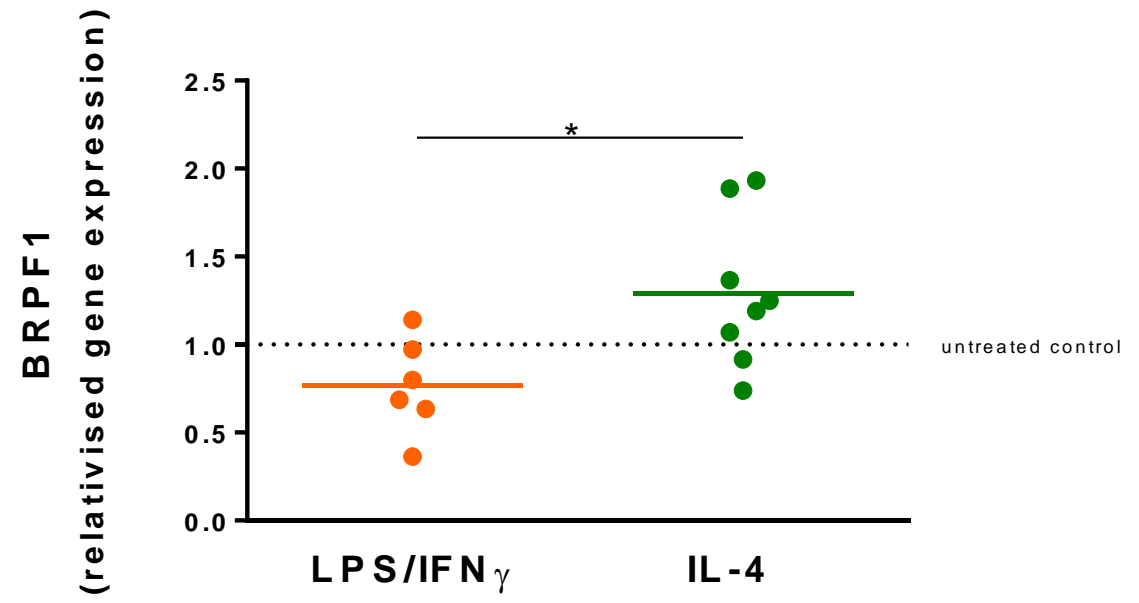


C

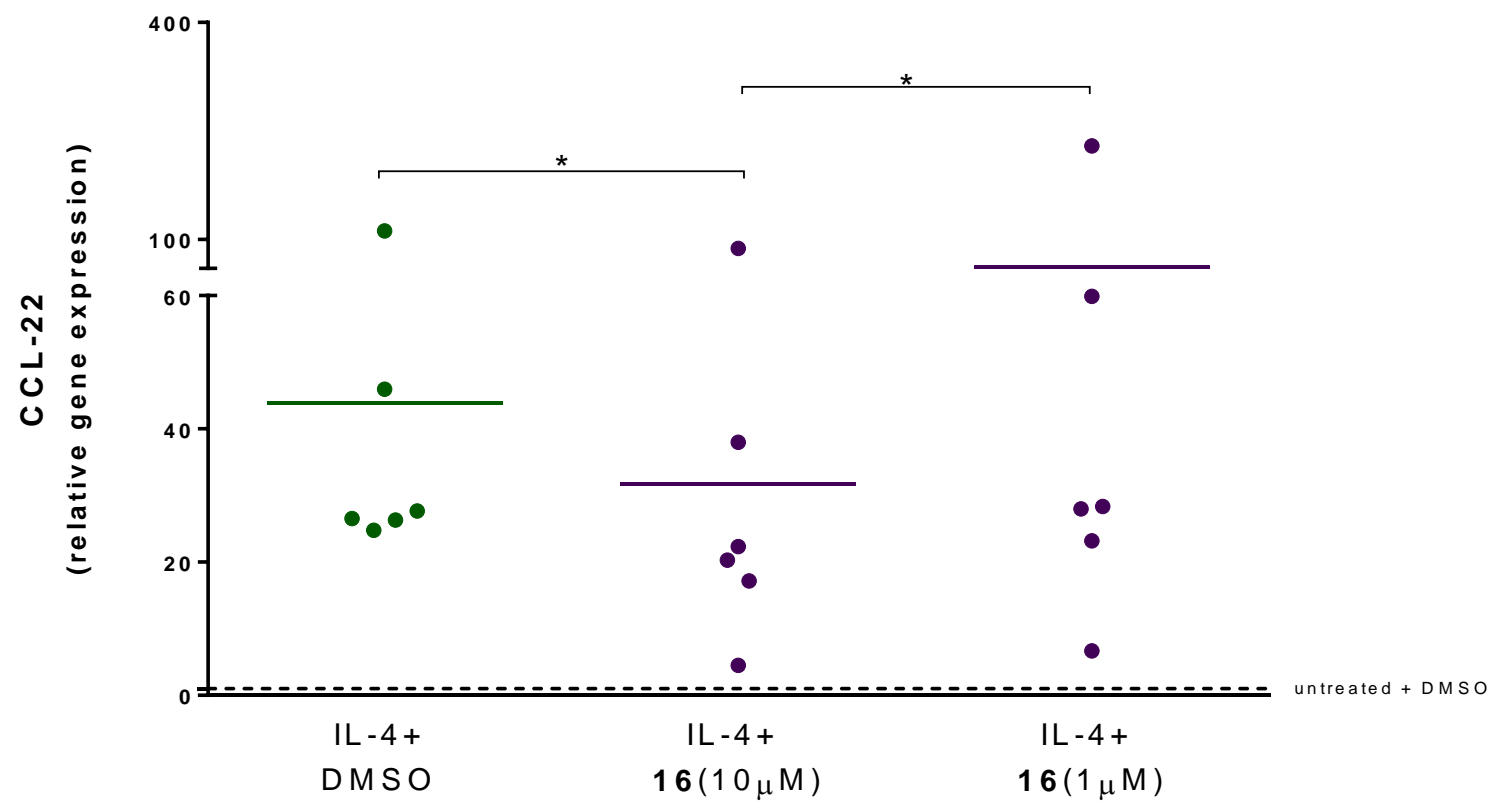

Figure 4. Alveolar Macrophages (AM) were isolated from lung resections of non-smoker, ex-smoker and smoker subjects. Isolated AM were LPS/IFNY-stimulated $(100 \mathrm{ng} / \mathrm{ml})$ or IL-4-stimulated $(200 \mathrm{ng} / \mathrm{ml})$ during $24 \mathrm{~h}$ together with DMSO ( $\bullet, \bullet$, respectively). Subsequently, TNF and CCL-22 (A) or BRPF1 (B) gene expression were measured and plotted. Gene expression was relativised to untreated macrophages. (C) IL-4 stimulated alveolar macrophages were treated with DMSO or $16(\bullet)$ and CCL22 gene expression was measured and plotted. Gene expression was relativised to DMSO treated macrophages. $\left({ }^{*}=p<0.05\right.$, Wilcoxon comparison test) 


\section{TOC Graphic}

\section{Chemical structure as .gif}

Size requirements: less than $21.0 \times 5.5 \mathrm{~cm}$

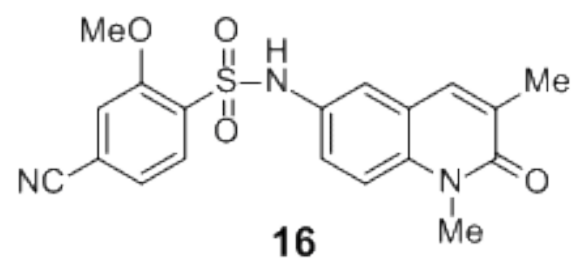

BRPF1 BRD $K_{D}=31 \mathrm{nM}$ BRPF2 BRD $K_{D}=110 \mathrm{nM}$ BRPF3 BRD $K_{D}=410 \mathrm{nM}$

\section{pan-BRPFs chemical probe}

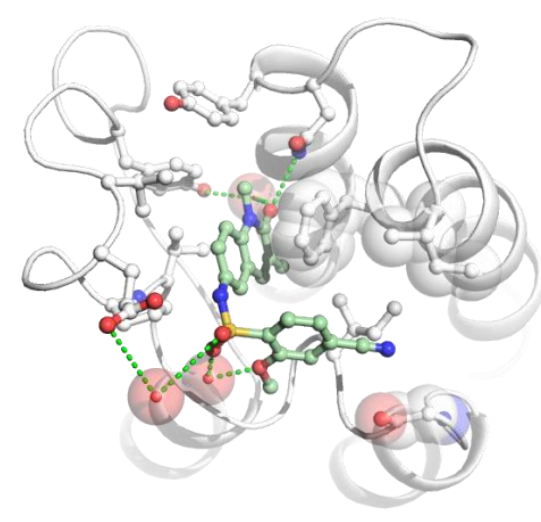

flipped binding mode

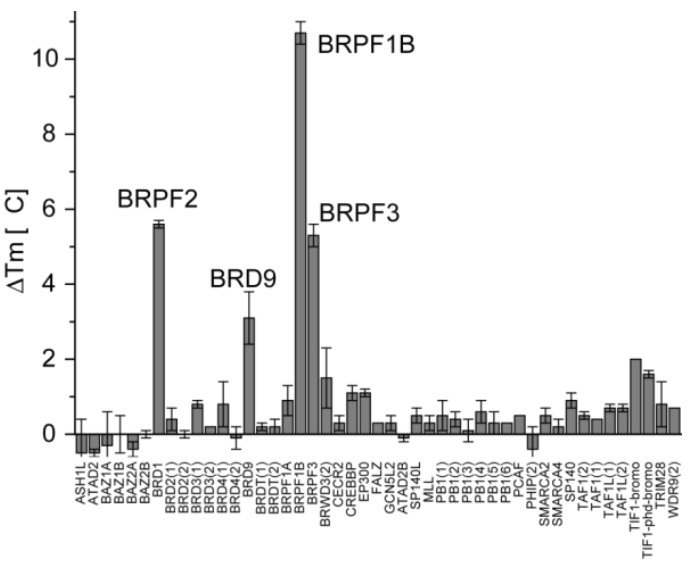

selective over non-class IV BRDs 